\title{
Techniques for Extraction of Brewer's Spent Grain Polyphenols: a Review
}

\author{
Luis F. Guido ${ }^{1}$ - Manuela M. Moreira ${ }^{2}$
}

\begin{abstract}
Million tons of brewer's spent grain (BSG) are annually produced worldwide as brewing industry by-products. BSG represents a valuable source of phenolic compounds, which have attracted much attention due to their diverse health benefits. Relevant strategies have been developed for their efficient extraction, in order to commercially exploit these resources. This review focuses on the current extraction methods used to obtain phenolic compounds from BSG, ranging from more traditional to advanced techniques. The commonly used methods are the conventional solid-liquid extractions, employing organic solvents, alkaline, and enzymatic reactions. However, the inherent difficulties in screening and obtaining these compounds have led to the development of advanced extraction techniques. Pressurized fluid extraction, supercritical extractions, and microwave-assisted and ultrasound-assisted extractions are some of the novel extraction techniques that have been recently explored. These techniques have been mostly applied for phenolic recovery from barley and malt, as well as other types of cereals. In this review, it is shown that these novel techniques may provide an innovative approach to extract phenolics from BSG or related products, following an in-depth discussion on the major strengths and weaknesses identified in each technique.
\end{abstract}

Keywords Brewer's spent grain · Phenolic compounds . Ferulic acid $\cdot p$-Coumaric acid $\cdot$ By-products

Luis F. Guido

lfguido@fc.up.pt

1 REQUIMTE/LAQV, Departamento de Química e Bioquímica, Faculdade de Ciências, Universidade do Porto, Rua do Campo Alegre 687, 4169-007 Porto, Portugal

2 REQUIMTE/LAQV, Instituto Superior de Engenharia do Porto, Instituto Politécnico do Porto, Rua Dr. António Bernardino de Almeida 431, 4200-072 Porto, Portugal

\author{
Abbreviations \\ BSG Brewer's spent grain \\ SLE Solid-liquid extraction \\ TPC Total phenolic content \\ DW Dry weight \\ GAE Gallic acid equivalents \\ FA Ferulic acid \\ $p$-CA $p$-Coumaric acid \\ HBAs Hydroxybenzoic acids \\ HCAs Hydroxycinnamic acids \\ FAE Ferulic acid esterase \\ SE Soxhlet extraction \\ SPE Solid-phase extraction \\ SFE Supercritical fluid extraction \\ PFE Pressurized fluid extraction \\ ASE Accelerated solvent extraction \\ RSM Response surface methodology \\ AX Arabinoxylans \\ AXOS Arabinoxylooligosaccharides
}

\section{Introduction}

Brewer's spent grain (BSG) is a residual by-product from one of the first steps in the brewing process in solubilizing the malt and cereal grains to ensure adequate extraction of the wort (Fillaudeau et al. 2006). BSG is the most significant byproduct in the brewing process, comprising $85 \%$ of total byproducts generated, $31 \%$ of original malt weight, and $20 \mathrm{~kg}$ per 1001 of beer produced (Gupta et al. 2010). 
The barley grain husks obtained as solid residue after the wort production basically constitute BSG. This solid residue contains water-insoluble proteins in addition to the husk, pericarp, and seed coat of the original barley grain (Mussatto 2009, 2014; Mussatto et al. 2006). Protein and fiber account for 20 and $70 \%$ of BSG dry matter, respectively, while the starch content of BSG is insignificant (due to the absence of starchy endosperm). BSG is also rich in phenolic compounds, particularly ferulic and $p$-coumaric acids (Mussatto et al. 2007b; Meneses et al. 2013; Bartolomé et al. 2002; Bartolomé and GómezCordovés 1999), along with oligosaccharides and polysaccharides (Mussatto et al. 2006; Carvalheiro et al. 2004).

The chemical composition as well as the potential applications for BSG is well reviewed in several recently published articles (Mussatto 2009, 2014; Mussatto et al. 2006; McCarthy et al. 2013a; Aliyu and Bala 2011). However, despite the vast majority of applications in different areas, BSG use as a source of phenolic compounds is still under exploited. Considerable advances in this field have been recently made, and while some research articles exist (Meneses et al. 2013; Mussatto et al. 2007b; McCarthy et al. 2013b; Moreira et al. 2013), no update has been made of the research carried out in the last years. Therefore, this review places a specific focus on the main extraction techniques applied for the recovery of phenolic compounds present in BSG. Whenever the extraction method has not been applied to BSG, examples of other similar matrices, such as malt or barley, will be given aiming to demonstrate its potential application.

\section{BSG as a Valuable By-Product}

At present, BSG has been widely used as an animal feed (Huige 2006; Kasperovich et al. 2009); however, with the increased cost of disposal of the solid fraction, alternative uses are highly sought-after (Mussatto 2009; Ktenioudaki et al. 2012; Awolu and Ibileke 2011). Over the past few years, attempts have been made to use BSG in biotechnological processes, such as substrate for microorganisms and enzyme production (Robertson et al. 2010; Terrasan et al. 2010), for bioethanol production (Mussatto et al. 2013; Xiros and Christakopoulos 2009; Awolu and Ibileke 2011), or as a source of value-added products, such as xylose (Mussatto and Roberto 2008), arabinose (Carvalheiro et al. 2004), oligomeric and polymeric hemicelluloses (Roos et al. 2009), and phenolic compounds (Moreira et al. 2012, 2013; McCarthy et al. 2013b; Meneses et al. 2013). The presence of cellulose, hemicellulose, and lignin, as well as the amount of readily available substances, such as sugars and amino acids, aids in its utilization as feed for ruminants. BSG consumption has been investigated for a range of animals, including poultry, pigs, fish, and chicken (Belibasakis and Tsirgogianni 1996; Dhiman et al. 2003; Mussatto et al. 2006). Since BSG is derived from materials utilized for humans, it can be incorporated into human diets, such as breads and snacks, especially where there is need to boost the fiber contents, decrease the calorific content, and increase the protein content of food products (Huige 2006; Mussatto et al. 2006). High protein flour prepared from BSG can be successfully incorporated into a number of bakery products, such as breads, muffins, cookies, among others (Huige 2006). A recent publication reported that bioactive compounds extracted by supercritical $\mathrm{CO}_{2}$ from $\mathrm{BSG}$ were microencapsulated to enrich fish burgers (Spinelli et al. 2016a).

Ethanol production from lignocellulosic biomasses raises a global interest because it represents a good alternative to petroleum-derived energies and reduces the food versus fuel conflict generated by first-generation ethanol. Xiros et al. (2008) and Xiros and Christakopoulos (2009) found that Neurospora crassa and Fusarium oxysporum have an exceptional ability of converting cellulose and hemicellulose directly to ethanol through the consecutive steps of hydrolysis of the polysaccharides and fermentation of the resulting oligosaccharides by secreting all the necessary enzyme systems. They reported an ethanol yield of 74 and $109 \mathrm{~g} / \mathrm{kg}$ of dry BSG by $N$. crassa and F. oxysporum, respectively, under microaerobic conditions (Xiros et al. 2008; Xiros and Christakopoulos 2009). In this study, alkaline acid pretreated BSG. Liguori et al. (2015) have recently evaluated BSG for ethanol production after enzymatic hydrolysis with commercial enzymes. When the hydrolysate was supplemented with yeast extract, $12.79 \mathrm{~g} / \mathrm{L}$ of ethanol, corresponding to $0.28 \mathrm{~g}$ of ethanol per grams of glucose consumed (55\% efficiency), was obtained within $24 \mathrm{~h}$.

The polysaccharide, protein, and high moisture contents of BSG make it susceptible for cultivation of microorganisms. Several studies have demonstrated that BSG is a suitable medium for isolation and maintenance of unknown strains and highly suitable for screening and production of new biologically active substances (Mussatto et al. 2006; Mussatto 2009; Robertson et al. 2010; Wang et al. 2001).

The reuse of BSG in the brewing process can be attractive from the point of view of brewery economics. Brányik et al. (2001) proposed another alternative for BSG reuse in breweries. These authors developed a simple method to obtain a cellulose-based carrier from BSG, sequentially pretreated with $\mathrm{HCl}$ and $\mathrm{NaOH}$ solutions, to be used for brewing yeast immobilization in a continuously operating bubble column reactor. The results obtained suggest that BSG was very efficient, due to its high yeast loading capacity. The feasibility of using BSG as a source for lignocellulosic yeast carrier (LCYC) production, after either caustic or combined acid caustic treatment, was demonstrated (Pires et al. 2012).

The cell walls of BSG are rich in cellulose and noncellulosic polysaccharides, which can be degraded into their corresponding constituents by hydrolytic procedures (hydrothermal, enzymatic, or acidic) (Mussatto et al. 2006; Mussatto 2009). A wide variety of arabinooligoxylosides with different structural features can be obtained according to the hydrolysis 
process used (Mussatto 2009). These compounds are of industrial interest, mainly in the food industry. They can be purified for immediate use or can be applied as precursors of food grade chemicals or as energy sources in microbial fermentations.

When compared with other lignocellulosic materials, BSG appears to be a more economical alternative to produce xylitol. BSG has been reported to be easily and readily utilized as a fermentation medium by the yeasts Debaryomyces hansenii (Carvalheiro et al. 2005; Duarte et al. 2004) and Candida guilliermondii where they grow and produce xylitol (Mussatto and Roberto 2008).

One of the major challenges in the large-scale production of lactic acid is the cost of the raw materials. BSG has been evaluated as raw material for lactic acid production (Mussatto et al. 2007a, 2008).

A range of other applications has also been proposed for BSG. Okamoto et al. (2002) developed a process for producing charcoal bricks from BSG and evaluated their physical and chemical properties. Another possibility for the disposal of BSG is to use them to increase the porosity in brick (Russ et al. 2005). The low amount of ash coupled with the high amount of fibrous material (lignin, hemicellulose, and cellulose) makes BSG suitable for use in building materials. Application of BSG in wood-based particleboard manufacturing was recently reported for the first time (Klimek et al. 2017). Due to its low cost and easy availability, BSG has been tested as an adsorbent for several types of compounds (Mussatto et al. 2006). Pyrolysed spent grain was used as an adsorbent for removing volatile organic compounds from waste gases (Mussatto et al. 2006). BSG has also been utilized as adsorbents for heavy metals from aqueous solutions. Low et al. (2000) investigated the adsorption of cadmium and lead by BSG and found maximum adsorption capacities of 17.3 and $35.5 \mathrm{mg} / \mathrm{g}$, respectively. BSG was also tested as an adsorbent of acid orange 7 dye (AO7), a monoazo acid dye currently used in paper and textile industries, whose presence in effluents causes environmental problems (Pedro Silva et al. 2004). A recent work gives insights into chromium(III) biosorption onto spent grains residual from a Portuguese brewing industry both in batch and expanded bed column systems. Experimental studies involved unmodified spent grains and spent grains treated with $\mathrm{NaOH}$ (Ferraz et al. 2015).

\section{Phenolic Compounds: Their Occurrence in Brewer's Spent Grain}

BSG consists predominantly of the husk, pericarp, and seed coat and is largely made up of cell walls (Mussatto
2009, 2014; Mussatto et al. 2006). Since most of the phenolic compounds of the barley grain are contained in the husk and hydroxycinnamic acids accumulate in the cell walls, BSG is a potentially valuable source of these compounds (Meneses et al. 2013; Mussatto et al. 2007b; Szwajgier et al. 2010; Moreira et al. 2012, 2013; McCarthy et al. 2013b). These constituents, which have been considered the most important source of antioxidants in cereals, exist in free as well as in the bound form. The majority of free phenolics in barley are flavanols, whereas the bound phenolics are mainly phenolic acids (Dvořáková et al. 2008a,b; Robertson et al. 2010; Szwajgier et al. 2010).

Phenolic acids are intermediates in the phenylpropanoid pathway leading to the synthesis of lignin (Shivashankar et al. 2015). These compounds can be distinguished in two subgroups, i.e., the hydroxybenzoic (HBA) and hydroxycinnamic acids (HCA). The HBA content of BSG is generally very low when compared to the amount of HCA (Szwajgier et al. 2010; Athanasios et al. 2007). The levels of HBA present in BSG are reported in Table 1. Different levels of these phenolics have been found in BSG; however, the most abundant HBA is syringic acid. $p$ Hydroxybenzoic, vanillic, and protocatechuic acids were also found, but in lesser amounts. Barley variety, time of harvest, and the characteristics of the growing region have accounted for the differences found in phenolic acids by Athanasios et al. (2007) and Szwajgier et al. (2010).

The occurrence of hydroxycinnamates in BSG is given in Table 2. There is evidence that ferulic (FA) and $p$-coumaric acids ( $p$-CA) are the most abundant members among HCA present in BSG (Mussatto et al. 2007b; Bartolomé et al. 2002; Robertson et al. 2010; Szwajgier et al. 2010; Athanasios et al. 2007; Moreira et al. 2013; McCarthy et al. 2013b). Recent studies show that BSG consists of $1.16 \%$ monomeric and dimeric phenolic acids, with $53 \%$ of the monomeric phenolic acids accounted for FA. Also, the vast majority of phenolic acids were found to be in the bound form (Dvořáková et al. 2008a). It has been reported that following FA and $p$-CA, the next most abundant HCA in BSG was found to be sinapic, followed by caffeic acid (Szwajgier et al. 2010).

Considering that FA and $p$-CA have antioxidant properties and important industrial applications, the extraction of these acids from BSG offers new possibilities for the reuse of this industrial by-product in food, cosmetic, and/ or pharmaceutical areas. Therefore, the extraction and recovery of these compounds is an important field of discussion. BSG phenolic compounds can be recovered by various extraction methods, such as solid-liquid extraction, microwave-assisted extraction, and enzymatic and alkaline reactions, which are the focus of discussion of this review. 
Table 1 Content of hydroxybenzoic acids in BSG

\begin{tabular}{lll}
\hline Hydroxybenzoic acids (mg/100 g of dry matter) & Reference & \\
\cline { 2 - 3 } & Szwajgier et al. (2010) & Athanasios et al. (2007) \\
\hline Syringic acid & $6.5 \pm 0.1$ & $6.84 \pm 0.07$ \\
$p$-Hydroxybenzoic acid & $1.2 \pm 0.6$ & $1.15 \pm 0.02$ \\
Vanillic acid & $\mathrm{NR}$ & $3.49 \pm 0.01$ \\
Protocatechuic acid & $0.5 \pm 0.1$ & $\mathrm{NR}$ \\
\hline
\end{tabular}

Mean values of three replicates \pm SD

$N R$ not reported

\section{Methods of Extraction for Phenolic Compounds}

The analysis and determination of bioactive compounds in plant materials can be divided into different steps, namely sample pretreatment, extraction, isolation, and purification (Routray and Orsat 2012; Stalikas 2007). The first step can include maceration, homogenization, grinding, and milling, which may be preceded by air-drying or freeze-drying. Drying can be useful for increasing yield per unit weight of raw material, increasing storage life, and decreasing space requirement (Routray and Orsat 2012). However, some drying processes, including freeze-drying, can cause undesirable effects on the constituent profiles of samples; therefore, caution should be taken when planning the sample pretreatment (Dai and Mumper 2010). The maceration, grinding, milling, and homogenization steps can increase the contact surface area between the solvent and the sample containing the solute. These pretreatment steps lead to the breakdown of cellular structures which enhances further the yield of the bioactive compounds. In-depth analysis of various extraction studies (Mussatto et al. 2006; Huige 2006; Bartolomé et al. 2002; Tang et al. 2004; 2005) leads to the conclusion that the choice of pretreatment has not been coherent. Some of the properties that influence the pretreatment process are polarity, acidity, presence of hydroxyl groups and aromatic rings, concentration levels, and the complexity of the matrix (Routray and Orsat 2012; Stalikas 2007).
It has been evident that the choice of the proper extraction technique represents the most important step in the recovery and isolation of bioactive phytochemicals from plant materials. The source and the type of compounds to be extracted, the extraction method, and the type of solvent employed, sample particle size, as well as the presence of interfering substances, influence the extraction process. An additional cleanup step may be required for the removal of unwanted phenolic and non-phenolic compounds such as sugars, fats, organic acids, and terpenes (Stalikas 2007), or in some cases, to preconcentrate the phenolic compounds (Vichapong et al. 2010). Recently, several research articles have been published on the advancement of different extraction techniques for the recovery of bioactive compounds from cereal and cereal-based products, such as ultrasound-assisted extraction (Wang et al. 2013), supercritical fluid extraction (Fernandez et al. 2008; Spinelli et al. 2016b), microwave-assisted extraction (Routray and Orsat 2012; Moreira et al. 2012, 2013), and pressurized fluid extraction (Bonoli et al. 2004a,b; Milagros DelgadoZamarreño et al. 2009). Some of these non-conventional techniques are considered as "green techniques," as they comply with standards set by Environmental Protection Agency, USA. Following is a comprehensive survey of these techniques, from conventional to the most innovative ones, specially applied to extract phenolics from BSG or related products, with a view to having an in-depth discussion on the major strengths and weaknesses identified in each technique.
Table 2 Content of hydroxycinnamic acids in BSG

\begin{tabular}{|c|c|c|c|c|c|c|}
\hline \multirow{2}{*}{$\begin{array}{l}\text { Hydroxycinnamic } \\
\text { acids (mg/ } 100 \mathrm{~g} \text { of } \\
\text { dry matter) }\end{array}$} & \multicolumn{6}{|l|}{ Reference } \\
\hline & $\begin{array}{l}\text { Szwajgier } \\
\text { et al. (2010) }\end{array}$ & $\begin{array}{l}\text { Athanasios } \\
\text { et al. (2007) }\end{array}$ & $\begin{array}{l}\text { Hernanz } \\
\text { et al. } \\
(2001)\end{array}$ & $\begin{array}{l}\text { Robertson } \\
\text { et al. } \\
(2010)\end{array}$ & $\begin{array}{l}\text { Moreira } \\
\text { et al. } \\
(2013)\end{array}$ & $\begin{array}{l}\text { McCarthy } \\
\text { et al. } \\
(2013 b)\end{array}$ \\
\hline Ferulic acid & $336.3 \pm 16.0$ & $271.6 \pm 20.2$ & $195 \pm 14$ & $490 \pm 30$ & $149 \pm 7$ & $35 \pm 5$ \\
\hline$p$-Coumaric acid & $64.4 \pm 4.6$ & $137.3 \pm 11.5$ & $74 \pm 6$ & $180 \pm 60$ & $47 \pm 7$ & $6.7 \pm 0.1$ \\
\hline Sinapic acid & $42.0 \pm 1.1$ & $\mathrm{NR}$ & NR & NR & NR & NR \\
\hline Caffeic acid & $9.9 \pm 0.7$ & NR & NR & NR & NR & $0.8 \pm 0.1$ \\
\hline
\end{tabular}

Mean values of three replicates $\pm \mathrm{SD}$

$N R$ not reported 


\section{Solid-Liquid Extraction}

A large number of phenolics have been traditionally extracted from natural sources with organic solvents. Solid-liquid extractions (SLE) are the most commonly used procedures prior to analysis of phenolics in BSG samples, due to their ease of use, efficiency, and wide applicability (Vellingiri et al. 2014; Meneses et al. 2013; McCarthy et al. 2012, 2013b). This technique generally includes initial extraction with different solvents, such as methanol, ethanol, acetone, or the aqueous phase of this solvent mixtures; cleanup; and further fractionation by liquid-liquid extraction, usually with ethyl acetate or hexane, and followed by column chromatography or solidphase extraction. In a general outline, the SLE of phenolics consists of a direct extraction of the fresh or freeze-dried sample with an appropriate solvent using any extractor, homogenizer, or by ultrasonic bath for a particular time. Hot water baths are very commonly used for extraction of bioactive compounds. Meneses et al. (2013) have evaluated the efficiency of different solvent compositions (methanol, ethanol, acetone, hexane, ethyl acetate, water, methanol/water mixtures, ethanol/water mixtures, and acetone/water mixtures) for extracting antioxidant phenolic compounds from BSG by using hot water bath extraction with magnetic agitation. They have reported that all the produced extracts showed antioxidant activity, but the extract produced with $60 \%(\mathrm{v} / \mathrm{v})$ acetone had the most elevated content of total phenolics $(9.90 \pm 0.41 \mathrm{mg}$ gallic acid equivalents $(\mathrm{GAE}) / \mathrm{g} \mathrm{DW})$. McCarthy et al. (2013b) have also assessed the total phenolic content (TPC) of pale and black BSG samples, which were extracted with acidified methanol $(\mathrm{HCl} / \mathrm{methanol} /$ water, $1: 80: 10 \mathrm{v} / \mathrm{v} / \mathrm{v})$ and incubated at room temperature $\left(25^{\circ} \mathrm{C}\right)$ for $2 \mathrm{~h}$. The TPC obtained for pale and black BSG was $1.26 \pm 0.10$ and $4.53 \pm 0.16 \mathrm{mg} \mathrm{GAE} / \mathrm{g} \mathrm{DW}$, respectively. In another study carried out by Vellingiri and coworkers (2014), they used a two-step solvent extraction with ethanol $80 \%$ for $2 \mathrm{~h}$ at room temperature, in darkness, under stirring at $150 \mathrm{rpm}$ in an orbital shaker for phenolic recovery. They reported that the second step of extraction led to an extract less concentrated in terms of total phenolics than the first extraction step, $0.652 \pm 0.042$ and $1.451 \pm 0.182 \mathrm{mg} \mathrm{GAE} / \mathrm{g} \mathrm{DW}$, respectively.

Even though SLE produces good recovery of phenolic compounds, some drawbacks have been reported, such as the requirement of a huge amount of solvents, long extraction time, limited choice of solvents due to its food quality, as well as the possible degradation of target compounds. Moreover, this type of extraction may also extract non-phenolic compounds, such as chlorophylls, fats, terpenes, waxes, and others, which are not desired. This may lead to a requirement for additional procedures to remove these unwanted impurities from the extracts, thus increasing the cost of extraction as well as introducing several analytical artifacts resulting in potential losses of the analyte. Numerous studies have been conducted to extract phenolic compounds from BSG using SLE; however, some compounds are retained in the polysaccharide-lignin network by hydrogen or hydrophobic bonding, which are not accessible with a solvent in a routine extraction process. Therefore, the majority of approaches use the basis of either enzymatic hydrolysis or saponification (with 1-4 M $\mathrm{NaOH}$ ) as will be pointed out in the following two subsections.

\section{Alkaline Hydrolysis}

Alkaline hydrolysis has been another SLE technique widely used for phenolic recovery from BSG (Mussatto et al. 2007b; Bartolomé et al. 2002; Santos et al. 2003; Hernanz et al. 2001; McCarthy et al. 2012; Reis and Abu-Ghannam 2014; McCarthy et al. 2013b; Mandalari et al. 2005; Jay et al. 2008). Table 3 details the alkaline extraction conditions that have been used to extract phenolic compounds, mainly FA and $p$-CA, from BSG.

Hernanz et al. (2001) analyzed the HCAs and FA dehydrodimer content in BSG after an alkali hydrolysis using $2 \mathrm{M} \mathrm{NaOH}$ followed by incubation at $20^{\circ} \mathrm{C}$ for $16 \mathrm{~h}$ under $\mathrm{N}_{2}$. They observed that BSG exhibits fivefold higher levels of FA, $p$-CA, and FA dehydrodimers than the unprocessed barley grains, with $p$-CA content ranging from $565 \pm 39$ to $794 \pm 58 \mu \mathrm{g} / \mathrm{g}$ and FA from $1860 \pm 190$ to $1948 \pm 143 \mu \mathrm{g} / \mathrm{g}$. In 2002, Bartolomé et al. (2002) evaluated the total pentose (xylose and arabinose) and HCA (FA and $p$-CA) content in eight lots of BSG preserved by different methods (freeze-drying, oven-drying, and freezing). HCA content was determined using the same conditions as Hernanz et al. (2001), but the $\mathrm{NaOH}$ concentration was $1 \mathrm{M}$. The total alkali-extractable HCA content of the samples varied between 0.17 and $0.24 \%$ dry weight for FA and between 0.068 and $0.121 \%$ dry weight for $p$-CA. Mussatto et al. $(2007 \mathrm{a}, \mathrm{b})$ investigated the simultaneous effects of the variables $\mathrm{NaOH}$ concentration $(1.0,1.5$, and $2.0 \%, \mathrm{w} / \mathrm{v})$, temperature $\left(80,100\right.$, and $\left.120^{\circ} \mathrm{C}\right)$, and reaction time $(30,60$, and $90 \mathrm{~min})$, on the alkaline hydrolysis of BSG, using a solid-liquid ratio of 1:20 (w/w). Under the best alkaline hydrolysis conditions $\left(2 \% \mathrm{NaOH}, 120^{\circ} \mathrm{C}, 90 \mathrm{~min}\right)$, $0.286 \%$ of FA was obtained. Despite the fact that this alkaline hydrolysis enables to obtain a higher FA recovery and uses less drastic conditions than the other processes described (Bartolomé et al. 2002; Santos et al. 2003; Hernanz et al. 2001), a pretreatment with dilute sulfuric acid is required, making this methodology time consuming and laborious. The BSG phenolic extract which provides the highest FA $(27.31 \pm 0.69 \mu \mathrm{g} / \mathrm{mL})$ and TPC $(0.732 \pm 0.020 \mathrm{mg} \mathrm{GAE} /$ $\mathrm{mL}$ ) was obtained after an alkaline hydrolysis using $1 \mathrm{M}$ $\mathrm{NaOH}$ at room temperature for $16 \mathrm{~h}$. The differences found in FA, $p$-CA, and TPC among the applied alkaline hydrolysis processes could be explained not only by the conditions used in the assay, as also through the differences in BSG 
Table 3 Efficiency and conditions used to extract phenolic compounds from BSG using alkaline hydrolysis

\begin{tabular}{|c|c|c|c|c|}
\hline Conditions & FA content & $p$-CA content & TPC & Reference \\
\hline $2 \mathrm{M} \mathrm{NaOH}, 20^{\circ} \mathrm{C}, 16 \mathrm{~h}$ under $\mathrm{N}_{2}$ & $\begin{array}{l}1860 \pm 190 \text { to } \\
1948 \pm 143 \mu \mathrm{g} / \mathrm{g}\end{array}$ & $\begin{array}{l}565 \pm 39 \text { to } \\
\quad 794 \pm 58 \mu \mathrm{g} / \mathrm{g}\end{array}$ & NR & Hernanz et al. (2001) \\
\hline $1 \mathrm{M} \mathrm{NaOH}, 20^{\circ} \mathrm{C}, 16 \mathrm{~h}$ under $\mathrm{N}_{2}$ & 0.17 to $0.24 \% \mathrm{DW}$ & 0.068 to $0.121 \% \mathrm{DW}$ & NR & Bartolomé et al. (2002) \\
\hline $1 \mathrm{M} \mathrm{NaOH}, 20^{\circ} \mathrm{C}, 16 \mathrm{~h}$ under $\mathrm{N}_{2}$ & NR & NR & $18.7 \% \mathrm{DW}$ & Santos et al. (2003) \\
\hline $0.5 \mathrm{M} \mathrm{KOH}, \mathrm{RT}, 2 \mathrm{~h}$ & $\begin{array}{l}1.78 \pm 0.50 \mu \mathrm{g} / \mathrm{mg} \\
\text { DW }\end{array}$ & $\begin{array}{l}1.97 \pm 0.16 \mu \mathrm{g} / \mathrm{mg} \\
\text { DW }\end{array}$ & NR & Mandalari et al. (2005) \\
\hline $\begin{array}{l}\text { Pretreatment with } \mathrm{H}_{2} \mathrm{SO}_{4}+2 \%(0.5 \mathrm{M}) \mathrm{NaOH} \text {, } \\
120^{\circ} \mathrm{C}, 90 \text { min }\end{array}$ & $\begin{array}{l}9.65 \mathrm{mg} / \mathrm{g} \text { solubilized } \\
\text { lignin }\end{array}$ & $\begin{array}{l}9.22 \mathrm{mg} / \mathrm{g} \text { solubilized } \\
\text { lignin }\end{array}$ & NR & Mussatto et al. $(2007 a, b)$ \\
\hline $4 \mathrm{M} \mathrm{NaOH}, \mathrm{RT}$ in dark, $24 \mathrm{~h}$ under $\mathrm{N}_{2}$ & $51.00 \%$ & $27.72 \%$ & NR & Jay et al. (2008) \\
\hline $1 \mathrm{M} \mathrm{NaOH}, \mathrm{RT}, 16 \mathrm{~h}$ & $27.3 \pm 0.7 \mathrm{mg} / \mathrm{mL}$ & NR & $\begin{array}{l}0.73 \pm 0.02 \mathrm{mg} \\
\mathrm{GAE} / \mathrm{mL}\end{array}$ & McCarthy et al. (2012) \\
\hline $4 \mathrm{M} \mathrm{NaOH}, 25^{\circ} \mathrm{C}$ at $100 \mathrm{rpm}$ in dark, $17 \mathrm{~h}$ & NR & NR & $1.8 \mathrm{~g} \mathrm{GAE} / \mathrm{kg} \mathrm{DW}$ & $\begin{array}{l}\text { Reis and Abu-Ghannam } \\
\text { (2014) }\end{array}$ \\
\hline
\end{tabular}

$N R$ not reported, $R T$ room temperature

characteristics, namely time of harvest and the characteristics of the growing region.

\section{SLE Coupled to Enzymatic Hydrolysis}

Enzymatic hydrolysis, as previous step to the solid-liquid extraction, has been often used for release of phenolic compounds from BSG. An overview of the results obtained of enzymatic hydrolysis of HCAs, namely FA and $p$-CA, from BSG is shown in Table 4.

Bartolomé et al. (1997) reported that an esterase from Aspergillus niger (FAE-III) was able to release $3.3 \%$ of the total FA from BSG. Moreover, they observed that the presence of a xylanase from Trichoderma viride increased this release up to $30 \%$. Probably, the action of the xylanase on BSG solubilizes low-molecular-mass feruloylated material, which is further degraded by the esterase to produce FA. Further, due to the high cost of pure enzymes, the same authors tested the use of three different commercial enzyme preparations (Viscozyme L, Ultraflo L, and Lallzyme) that also exhibit cinnamic acid esterase activity (Bartolomé and GómezCordovés 1999). Incubation of Ultraflo L (1.3 U/g substrate, $24 \mathrm{~h}$ ) with BSG released $70 \%$ of the total alkali-extractable FA and $8 \%$ of the total alkali-extractable $p$-CA. Under the same conditions, Viscozyme L and Lallzyme released, respectively, 33 and $55 \%$ of the total alkali-extractable FA and 0.8 and

Table 4 Efficiency and enzyme preparations used to extract phenolic compounds from BSG using enzymatic hydrolysis

\begin{tabular}{|c|c|c|c|}
\hline Enzyme preparation & FA released & $p$-CA released & Reference \\
\hline FAE from Aspergillus niger & $3.3 \%$ & NR & Bartolomé et al. (1997) \\
\hline $\begin{array}{l}\text { FAE from A. niger }+ \text { xylanase from Trichoderma } \\
\quad \text { viride }\end{array}$ & $30 \%$ & NR & \\
\hline Ultraflo L commercial enzyme & $70 \%$ & $8 \%$ & Bartolomé and \\
\hline Viscozyme L commercial enzyme & $33 \%$ & $0.8 \%$ & Gómez-Cordovés (1999) \\
\hline Lallzyme commercial enzyme & $55 \%$ & $1.60 \%$ & \\
\hline $\begin{array}{l}\text { Ultraflo L, a b-glucanase preparation from Humicola } \\
\text { insolens }\end{array}$ & $65 \%$ & $9 \%$ & Faulds et al. $(2002,2004)$ \\
\hline FAE + xylanase from Streptomyces avermitilis CECT 3339 & $43 \%$ & $<9 \%$ & Bartolomé et al. (2003) \\
\hline Ultraflo $\mathrm{L}+T$. viride xylanase & $150 \mathrm{mg} / \mathrm{g} \mathrm{DW}$ & NR & Faulds et al. (2006) \\
\hline $\begin{array}{l}\text { FAE + xylanase }+ \text { arabinofuranosidases from Penicillium } \\
\text { brasilianum IBT } 20888\end{array}$ & $85 \%$ & $90 \%$ & Panagiotou et al. (2006) \\
\hline Econase commercial enzyme & $0.007 \%$ & $0.003 \%$ & Forssell et al. (2008) \\
\hline Spezyme commercial enzyme & $0.007 \%$ & $0.003 \%$ & \\
\hline Depol 740 commercial enzyme & $0.59 \%$ & $0.055 \%$ & \\
\hline Depol 686 commercial enzyme & $0.42 \%$ & $0.037 \%$ & \\
\hline Crude enzyme extract of Fusarium oxysporum & $49 \%$ & NR & Xiros et al. (2009) \\
\hline $\begin{array}{l}\text { Monoenzymes feruloyl esterase (FAE, FoFaeC-12213) } \\
\text { and xylanase (Trichoderma longibrachiatum M3) }\end{array}$ & $15 \%$ & NR & \\
\hline FAE from Lactobacillus acidophilus $\mathrm{K} 1$ & $7.00 \pm 0.07 \mathrm{mg}_{\mathrm{FA}} / 100 \mathrm{~g}$ & $1.9 \pm 0.1 \mathrm{mg}_{\mathrm{CA}} / 100 \mathrm{~g}$ & Szwajgier et al. (2010) \\
\hline
\end{tabular}

FAE ferulic acid esterase, $N R$ not reported 
$1.6 \%$ of the total alkali-extractable $p$-CA. Faulds et al. (2002, 2004) also investigated the ability of Ultraflo $L$, a $\beta$-glucanase preparation from Humicola insolens sold for reducing viscosity problems in the brewing industry, which exhibits activity against the methyl esters of ferulic, caffeic, p-coumaric, and sinapic acids, displaying mainly type-B feruloyl esterase activity. They observed a release of $65 \%$ of the available FA together with three forms of diferulate, especially the 8,5' benzofuran form, and a $9 \%$ release of $p$-CA from BSG. These results demonstrate that FA and its dimeric forms present in BSG require the addition of more than a xylanase. This suggests either that FA is not solely attached to arabinoxylan in the barley cell wall or that the cell wall polysaccharides in BSG hinder the accessibility of enzymes to the ferulates, due to processing treatments. Recently, Xiros et al. (2009) studied the factors affecting FA release from BSG by the crude enzyme extract of Fusarium oxysporum. More than double amount of FA release $(1 \mathrm{mg} / \mathrm{g}$ dry BSG, nearly $49 \%$ of the alkali-extractable FA) was observed during hydrolytic reactions by the crude enzyme extract compared to hydrolysis by the monoenzymes feruloyl esterase (FAE, FoFaeC-12213) and xylanase (Trichoderma longibrachiatum M3) $(0.32 \mathrm{mg} / \mathrm{g}$ dry BSG corresponding to $15 \%$ of alkaliextractable FA content). These results are in agreement with the earlier studies, which demonstrated the significance of the presence of many different auxiliary hydrolytic activities for the efficient FA release from BSG. Szwajgier et al. (2010) reported the use of a novel FAE from Lactobacillus acidophilus K1 for the release of phenolic acids from BSG. The enzyme released $7.00 \pm 0.07 \mathrm{mg}$ FA from $100 \mathrm{~g}$ of BSG after $3 \mathrm{~h}$ of incubation (approx. 2.1\% of the total alkali-extractable FA present in BSG). The maximal content of the released $p$-CA was $1.88 \pm 0.10 \mathrm{mg} / 100 \mathrm{~g}$ of BSG.

Enzymatic pretreatment has been considered as a novel and an effective way to release bounded compounds and increase overall yield. The addition of specific enzymes like cellulase, $\alpha$-amylase, and pectinase during extraction enhances recovery by breaking the cell wall and hydrolyzing the structural polysaccharides and lipid bodies (Azmir et al. 2013). Enzymeassisted extraction is agro-food compatible. However, according to the reported data (Table 4), FA extraction from BSG utilizing enzymes as extraction agents yielded less phenolics than in the alkaline hydrolysis and increase the overall costs of analysis.

\section{Soxhlet Extraction}

Soxhlet method is still used as a standard technique in almost all cases for comparison of advanced methods in terms of their yield (Moreira et al. 2012). Solvents, such as methanol, ethanol, acetone, diethyl ether, dichloromethane, n-hexane, and ethyl acetate, have been used for Soxhlet extraction of phenolics (Stalikas 2007; Sun and Sun 2001; Moreira et al. 2013;
Table 5 Main advantages and disadvantages of Soxhlet extraction

\begin{tabular}{ll}
\hline Advantages & Disadvantages \\
\hline Simple to perform & Long extraction time \\
Easy implementation & Thermolabile compound loss \\
Not require specialized personnel & Large amounts of solvents \\
No filtration procedure & Agitation cannot be used \\
Repeatedly brings fresh solvent & Expensive and hazardous solvents \\
\hline
\end{tabular}

Bohnsack et al. 2011). However, very polar phenolic acids (benzoic and cinnamic acids) could not be completely extracted with pure organic solvents, and mixtures of alcohol-water or acetone-water are recommended (Stalikas 2007; Meneses et al. 2013). Most of these solvents must be used with care, as they are toxic for humans and dangerous for the environment. Moreover, the solvent must be separated from the final extract, especially if the product is to be used in food applications, requiring an evaporation/concentration step for recovery. Luque de Castro and García-Ayuso (1998) outlined the importance of Soxhlet extraction (SE) as a model to which the performance of other conventional and new extraction techniques is referred. The main drawbacks and advantages of SE are listed in Table 5.

SE is a generally well-established technique. Wide industrial applications and better reproducibility and efficiency have favored significantly their widespread use over other novel extraction methods such as ultrasound-assisted, microwave-assisted, supercritical fluid, or accelerated solvent extractions. However, the main drawbacks mentioned lead to criticism of the conventional SE method, placing problems in terms of sustainability and protection of the environment (Stalikas 2007 ; Wang and Weller 2006). Meanwhile, auxiliary features such as a vacuum pump, a membrane separation unit, a source of ultrasound and microwave, and supercritical fluids can be incorporated into the conventional Soxhlet method to improve its performance. Alternatively, hydrodistillation with hot water or direct steam should be used. However, at a high extraction temperature, some thermolabile compounds may be lost, which is the case for phenolics.

Moreira et al. (2012) applied SE, as a comparative technique, to extract phenolic compounds from BSG. Extraction was performed for $4 \mathrm{~h}$ with $150 \mathrm{~mL}$ of ethanol as the extracting solvent, and the reported yield of FA was $0.0014 \pm 0.0001 \%$. The reported yield, in association with the disadvantages mentioned in Table 5 , may be the reason why this type of extraction is so rarely used for phenolic recovery. Despite that, some studies reporting the Soxhlet extraction of phenolics from barley, one of the main raw materials used in beer production, have been found (Conde et al. 2008; Dudjak et al. 2004; Sun and Sun 2001). A comparison of different SE conditions and the phenolic content recovered from barley is given in detail in Table 6. Therefore, future 


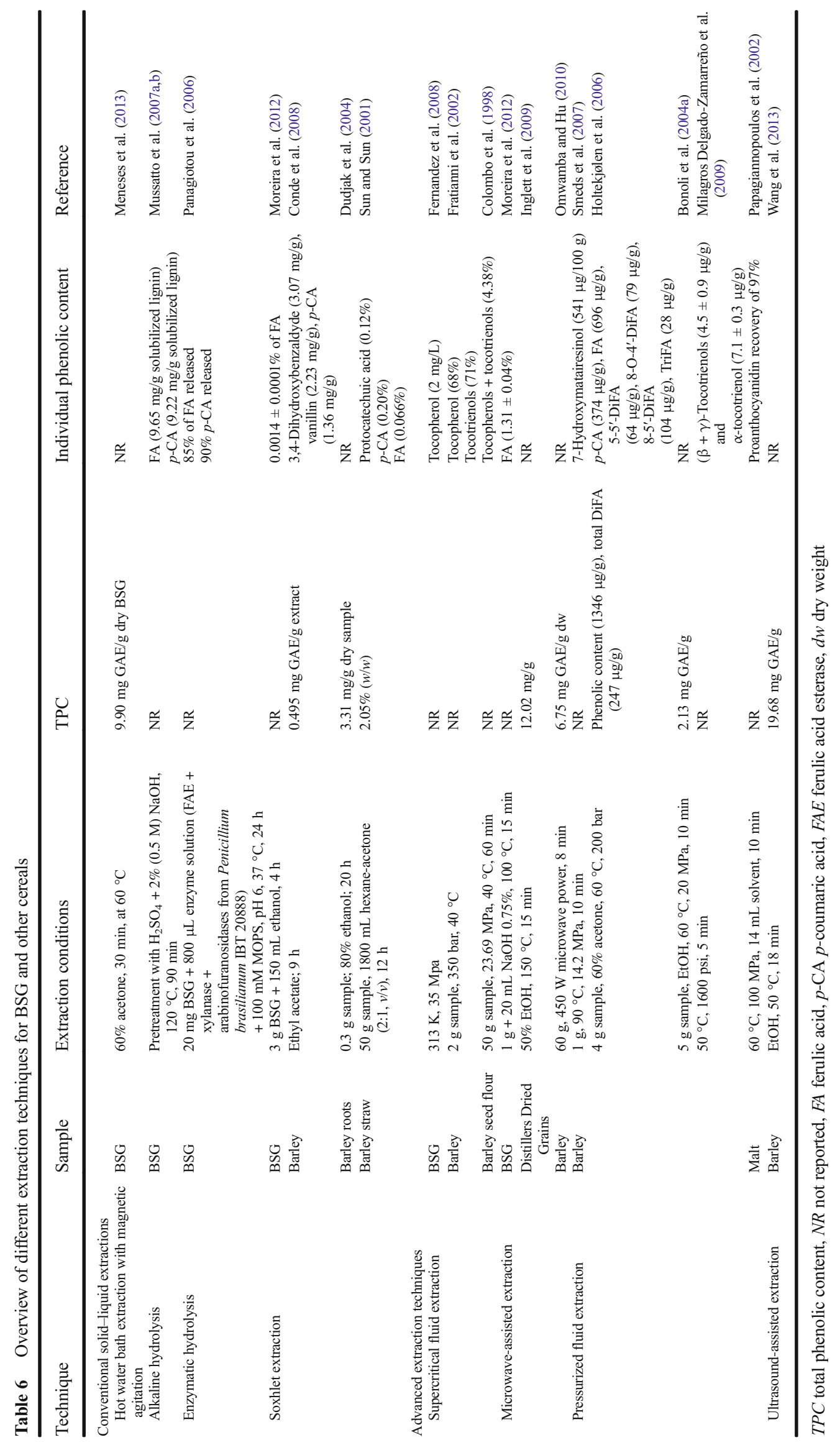


applications of this technique might be improved using other experimental conditions, such as the type of solvent, allowing combining the advantages of SE to an increase in the yield.

\section{Solid-Phase Extraction}

Most problems associated with SLE, such as less-thanquantitative recoveries, use, and disposal of large and expensive quantities of organic solvents, can be overcome with solid-phase extraction (SPE). With the use of SPE, there is an increase in sample throughout and minimal matrix interferences. This technique is used most often to prepare liquid samples and extract semivolatile or non-volatile analytes but can also be used with solids that are pre-extracted into solvents. The stationary phases are available in a wide variety of chemistries, adsorbents, and sizes so that it is necessary to select the most suitable product for each application and sample. Various adsorbents and elution solvents of varying $\mathrm{pH}$ have been applied for the recovery of phenolics from barley grains (Holtekjølen et al. 2006; Irakli et al. 2012; QuindeAxtell and Baik 2006). Irakli et al. (2012) compared four different solid-phase cartridges for the recovery of standard phenolic compounds: silica-based $\mathrm{C}_{18}$ (LiChrolut EN and BakerBond) and polymeric (Oasis HLB and Abselut Nexus). Polymeric cartridges provided good results, while $\mathrm{C}_{18}$-based phases afforded less satisfactory results for extracting more polar compounds. These authors have also shown that Abselut Nexus, which is a hydrophilic commercial sorbent based on the copolymer of methacrylatedivinylbenzene, exhibits similar recovery rates to Oasis HLB cartridges; Oasis HLB was therefore selected for extraction of phenolics since this sorbent is better for extracting more polar and offers a high specific surface area $\left(800 \mathrm{~m}^{2} / \mathrm{g}\right)$.

Several novel extraction techniques have been developed, such as microwave and ultrasound-assisted extractions, in order to seek for more environmentally friendly methods, decrease the solvent consumption, shorten the extraction time, increase the extraction yield, and enhance the quality of extracts. Techniques based on the use of compressed fluids as extracting agents, such as supercritical fluid extraction, pressurized fluid extraction, or accelerated solvent extraction, which are less labor intensive and more environmentally friendly, have also been applied in the extraction of phenolic compounds from BSG and other types of cereals (Fernandez et al. 2008; Bonoli et al. 2004a; Smeds et al. 2007; Moreira et al. 2012; Wang et al. 2013). Moreover, these techniques offer the possibility of working at elevated temperatures and/or pressures, greatly decreasing the time of extraction. In any case, these conventional techniques are still widely used as a comparison when an advanced extraction technique is applied (Moreira et al. 2012).

\section{Supercritical Fluid Extraction}

Supercritical fluid extraction (SFE) is another popular method applied for extracting many bioactive compounds (de Melo et al. 2014; Fernandez et al. 2008; Barbosa-Pereira et al. 2013; Pereira and Meireles 2010; Díaz-Reinoso et al. 2006). The supercritical state is reached when both the temperature and pressure are raised above their critical value. The supercritical fluid has characteristics of both gases and liquids. Compared with liquid solvents, supercritical fluids have several major advantages. Dissolving power of a supercritical fluid solvent depends on its density, which can be highly adjustable by changing the pressure and/or temperature. Furthermore, the supercritical fluid has a higher diffusion coefficient, lower viscosity, and surface tension than a liquid solvent, leading to more favorable mass transfer (Joana Gil-Chávez et al. 2013; Wijngaard et al. 2012; de Melo et al. 2014). A schematic diagram of a process-scale SFE system is shown in the Fig. 1.

During SFE, material is loaded into an extraction vessel, which is equipped with temperature controllers and pressure valves at both inlet and outlet to keep desired extraction conditions. The extraction vessel is pressurized with the fluid by a pump. The fluid and the dissolved compounds are transported to separators, where the solvation power of the fluid is decreased by decreasing the pressure or increasing the temperature of the fluid. The product is then collected via a valve located in the lower part of the separators. The fluid is further regenerated and cycled (Joana Gil-Chávez et al. 2013; de Melo et al. 2014; Herrero et al. 2010).

SFE is a clean method, considered environmental friendly as $\mathrm{CO}_{2}$ is generally used as the solvent. $\mathrm{CO}_{2}$ is safe, foodgrade, and widely available at a relatively low cost and high purity (Azmir et al. 2013). A disadvantage of using $\mathrm{CO}_{2}$ as a solvent is that it is relatively apolar, which can be overcome using modifiers (cosolvents) capable of hydrogen bonding, dipole-dipole, and other interactions with the analyte of interest, such as methanol, ethanol, acetonitrile, acetone, water, ethyl ether, and dichloromethane (Herrero et al. 2010; Pereira and Meireles 2010; Díaz-Reinoso et al. 2006). As evidenced from the literature, the modification of the solvent composition has led to the successful extraction of phenolic compounds from biological matrices (Joana Gil-Chávez et al. 2013; Díaz-Reinoso et al. 2006). However, for most very polar phenolics, the extraction efficiency of supercritical extraction is quite low, because the content of the organic modifier is not sufficient for their complete isolation (Stalikas 2007). For extraction of polyphenols, the addition of moderately polar modifier is crucial with most authors reporting zero yields when no ethanol is added (Wijngaard et al. 2012).

The supercritical carbon dioxide extraction of BSG has been recently reported (Spinelli et al. 2016b). Results indicate that an extraction time of $240 \mathrm{~min}$, temperature of $40{ }^{\circ} \mathrm{C}$, 
Fig. 1 Schematic diagram of a process-scale supercritical fluid extraction (SFE) system

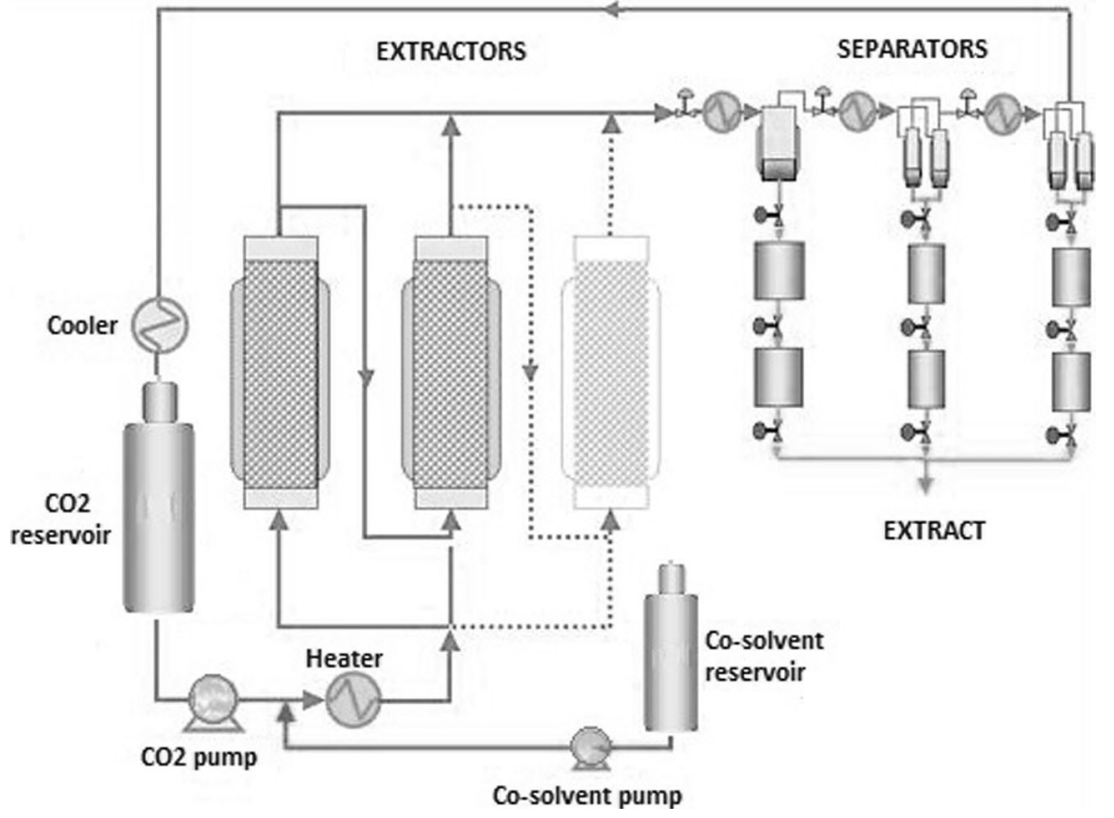

pressure of $35 \mathrm{MPa}$, and with $\mathrm{CO}_{2}+60 \%$ ethanol (v/v) were the best operating conditions to achieve the highest phenolic content. These results should be regarded with skepticism, as the characterization of the phenolic fraction was not conducted, and the conclusions were drawn from the spectrophotometric analyses. Our previous studies (data not published) have shown by HPLC-ESI-MS that FA and $p$-CA were almost negligible in the fractions obtained through $\mathrm{SC}-\mathrm{CO}_{2}$ and ethanol. The compounds detected in the HPLC chromatogram corresponded to the essential oil fraction of BSG, which accounts for $13 \%$ of its composition.

Fernandez et al. (2008) evaluated the use of supercritical fluid technology coupled with pretreatment processes for the recovery of tocopherol from raw and milled BSG. The SC$\mathrm{CO}_{2}$ extraction of BSG was performed at temperatures of 313 , 333 , and $353 \mathrm{~K}$ and at pressures from 10 to $35 \mathrm{MPa}$. The operating conditions selected to obtain the maximum yield were a temperature of $313 \mathrm{~K}$, a milling step to obtain a particle size of $0.85 \mathrm{~mm}$, and a pressure of $35 \mathrm{MPa}$. Under these conditions, BSG contained a tocopherol concentration in the extract of $2 \mathrm{mg} / \mathrm{L}$. Recently, Barbosa-Pereira et al. (2013) have evaluated the efficiency of the SFE technique to purify natural antioxidants obtained from brewery waste, namely from polyvinylpolypyrrolidone (PVPP). In beer production, a clarification step is essential to improve beer stability, and as a result of this process, PVPP sludge is obtained, which was analyzed by these authors. The most active fraction yielded by SFE (EC50 of $0.23 \mathrm{~g} / \mathrm{L}$ ) was obtained under the following conditions: temperature $40{ }^{\circ} \mathrm{C}$, pressure 140 bar, extraction time $30 \mathrm{~min}, \mathrm{CO}_{2}$ flow $3 \mathrm{~g} / \mathrm{min}$, ethanol $(6 \%)$ as a modifier, and modifier flow $0.2 \mathrm{~mL} / \mathrm{min}$. Several phenolic compounds, such as gallic, ferulic, and p-coumaric acids, were identified in the SFE fractions, and a total yield of $172.7 \mathrm{mg} / \mathrm{g}$ of fraction was obtained under the optimum conditions. Further SFE applications for phenolic extraction are reported in Table 6.

The most obvious advantages of SFE are that it is a clean and environmentally friendly technique. Direct $\mathrm{SC}-\mathrm{CO}_{2}$ extraction is not recommended for by-products obtained on a large scale and containing small amounts of bioactive compounds, as the case of BSG (Díaz-Reinoso et al. 2006). However, as suggested by Barbosa-Pereira et al. (2013), SFE could be used to purify crude extracts of BSG yielded by organic solvents by concentrating the bioactive compounds (e.g., phenolic compounds) in the extract and also by removing contaminants, improving their purity and their biological properties without thermal or chemical degradation.

To conclude, the economics and onerous operating conditions of the SFE processes have restricted their applications to some very specialized fields such as essential oil extraction, decaffeination of coffee beans, extraction of a acids from hops (Wijngaard et al. 2012), and to university research (de Melo et al. 2014; Herrero et al. 2010).

\section{Microwave-Assisted Extraction}

Microwave-assisted extraction (MAE) is another advanced method of extraction, which has become popular for the separation of bioactive compounds from plant matrices. Microwaves are electromagnetic waves, which are usually operated at a frequency of $2.45 \mathrm{GHz}$ that can access biological matrices and interact with polar molecules, such as water, and generate heat. The temperature will rise, which generally leads to enhanced extraction efficiency (Joana Gil-Chávez et al. 2013; Routray and Orsat 2012). By using MAE, the extraction 
time can be reduced in comparison to conventional extraction methods (Moreira et al. 2012; Inglett et al. 2009). MAE extraction efficiency principally depends on microwave energy, treatment time, and temperature used. It should be noted that in general, temperature increase enhances extraction rates of solutes due to an increase in diffusion rates and in the capacity of solvents to solubilize solutes, a better disruption of solutematrix bonds, as well as the decrease in surface tension and in viscosity of the solvent (Wijngaard et al. 2012). Very high extraction temperatures can however generate unwanted compounds. For example, Tsubaki et al. (2010) reported that the proportion of polyphenol in the extract of tea residue increased from 25.3 to $74.4 \%$ when the temperature was increased from 110 to $230{ }^{\circ} \mathrm{C}$ using MAE. However, 5hydroxymethylfurfural, a potentially harmful compound, was also formed at $230{ }^{\circ} \mathrm{C}$. Therefore, caution should be taken while increasing the temperature in MAE. Liazid et al. (2007) evaluated the stability of 22 phenolic compounds of different families (benzoic acids, benzoic aldehydes, cinnamic acids, catechins, coumarins, stilbens, and flavonols) under working temperatures ranging from 50 to $175^{\circ} \mathrm{C}$. They concluded that all the compounds studied are stable up to $100^{\circ} \mathrm{C}$, whereas at $125^{\circ} \mathrm{C}$, a significant degradation of epicatechin, resveratrol, and myricetin may occur. They observed that compounds with a greater number of hydroxyl-type substituents are more easily degraded with increased MAE temperatures.

There are two types of commercially available MAE systems: closed extraction vessels under controlled pressure and temperature or open vessels under atmospheric pressure (Valérie 2000; Routray and Orsat 2012; Wang and Weller 2006), which are commonly named either pressurized MAE (PMAE) and focused MAE (FMAE), respectively. Both systems are schematized in Valérie's review (Valérie 2000). The closed MAE system is generally used for extraction under drastic conditions such as high extraction temperature. The pressure in the vessel essentially depends on the volume and the boiling point of the solvents. The FMAE system can be operated at a maximum temperature determined by the boiling point of the solvents at atmospheric pressure.

Several classes of phenolic compounds have been efficiently extracted from a variety of cereals, such as oat bran (Stevenson et al. 2008; Dar and Sharma 2011), barley (Omwamba and Hu 2010), wheat bran (Oufnac et al. 2007; Dar and Sharma 2011), rice bran oil (Zigoneanu et al. 2008; Dar and Sharma 2011), and distillers dried grains (Inglett et al. 2009). A MAE method for the recovery of phenolic compounds from BSG has been recently developed by our research group (Moreira et al. 2012). The influence of the MAE operational parameters (extraction time, temperature, solvent volume, and stirring speed) on the extraction yield of FA was investigated through response surface methodology (RSM). The results showed that the optimal conditions were 15-min extraction time, $100^{\circ} \mathrm{C}$ extraction temperature, $20 \mathrm{~mL}$ of $\mathrm{NaOH} 0.75 \%$, and maximum stirring speed. Under these conditions, the yield of FA was $1.31 \pm 0.04 \%(w / w)$, which was fivefold higher than that obtained with conventional SLE techniques usually applied to this matrix. The developed new extraction method considerably reduces extraction time, energy, and solvent consumption, while generating fewer wastes. Furthermore, HPLC-DAD-MS analysis indicated that other HCAs and several FA dehydrodimers, as well as one dehydrotrimer, were also extracted by the developed methodology. The MAE method previously reported has also been used to evaluate the phenolic composition and antioxidant activity of BSG extracts obtained from light (pilsen, melano, melano 80, and carared) and dark (chocolate and black) malts (Moreira et al. 2013). The TPC and antioxidant activity among the light BSG extracts were significantly different $(p<0.05)$ compared to dark extracts, with the pilsen BSG showing higher TPC (20 $\pm 1 \mathrm{mg} \mathrm{GAE} / \mathrm{g}$ dry BSG). In 2014, Coelho and coworkers published a study where they also used MAE in BSG samples, however for the extraction of arabinoxylans (AX) or arabinoxylooligosaccharides (AXOS), which are also potent antioxidants and radical scavengers (Coelho et al. 2014). The best conditions in terms of yield of extraction were achieved at $210{ }^{\circ} \mathrm{C}$, obtaining $43 \%$ of BSG AX + AXOS. At these conditions, a total amount of phenolic compounds of $0.34 \mu \mathrm{M} / \mathrm{mg}$ in equivalents of gallic acid and an antioxidant activity of $208 \mu \mathrm{M} / \mathrm{mg}$ in equivalents of trolox were obtained. MAE conditions and the phenolic content for BSG and other cereals are reported in Table 6 .

MAE has been considered as a potential alternative to traditional SLE for the extraction of metabolites from plants, which has been used to extract phenolic compounds for several reasons: (i) reduced extraction time, (ii) reduced solvent usage, and (iii) improved extraction yield. MAE is also comparable to other modern extraction techniques, such as SFE, due to its process simplicity and low cost. By considering economical and practical aspects, MAE is a strong novel extraction technique for the recovery of bioactive compounds. However, compared to SFE, an additional filtration or centrifugation is necessary to remove the solid residue during MAE. Furthermore, the efficiency of microwaves can be very poor when either the target compounds or the solvents are nonpolar or when they are volatile (Valérie 2000; Routray and Orsat 2012). MAE is faster and easier in comparison to conventional extraction processes, and it is recognized as a green technology because it reduces the use of organic solvent.

\section{Pressurized Fluid Extraction}

Pressurized fluid extraction (PFE) is a SLE technique which has been developed as an alternative to current extraction methods such as Soxhlet, maceration, percolation, or reflux, offering advantages with respect to extraction time, solvent consumption, extraction yields, and reproducibility. During 
PFE, pressure is applied, allowing the use of temperatures above the boiling point of solvents. Extracting at elevated temperatures can be advantageous due to changes in mass transfer and surface equilibria. Higher extraction temperatures will increase the mass transfer rate and extraction rates, because higher temperatures generally imply (i) an increase in analyte solubility, (ii) an increase in diffusion rates, (iii) better disruption of solute-matrix bonds, (iv) a decrease in viscosity of the solvent, and (v) decrease in solvent surface tension (Mendiola et al. 2007; Ramos et al. 2002; Mustafa and Turner 2011; Herrero et al. 2013). A typical schematic diagram of a PFE system is given in Fig. 2.

Accelerated solvent extraction (ASE) is a type of pressurized fluid firstly introduced in 1995 by Dionex. Extraction cells filled with solvent are held at elevated temperature and pressure without a continuous flow of solvent. Disposable filters (cellulose or fiber glass) automatically remove solid particulates from the extract, whereas adsorbents (silica, activated alumina) automatically remove interfering molecules from the extract. Multiple extraction methods can be run on the same sample or series of samples within a single batch. Compared with traditional SE, there is a dramatic decrease in the amount of both solvent and the extraction time for ASE. Particular attention should be paid to the ASE performed with high extraction temperature, which may lead to degradation of thermolabile compounds. Finally, while MAE gives extraction efficiencies comparable to SFE and ASE, with similar extraction times, it must be pointed out that the use of the latter two techniques requires a higher investment cost, mainly due to more expensive equipment (Wijngaard et al. 2012).

ASE is usually used for the extraction of high-temperature stable organic pollutants from environmental matrices. Until today, there are no studies concerning the application of the
ASE in samples of BSG for phenolic extraction. In fact, very few applications of ASE have been published in the field of phenolic extraction from barley (Smeds et al. 2007; Holtekjølen et al. 2006) and other cereals, such as wheat, corn, rice, and sorghum brans (Abdel-Aal et al. 2014; Barros et al. 2013; Pourali et al. 2010). Smeds et al. (2007) compared the performance of ASE with traditional acid and alkaline extractions for the recovery of lignans from bran extracts of 16 cereal species, in four nut species, as well as in two oilseed species (sesame seeds and linseeds). Their results showed a substantial reduction in extraction time and solvent consumption, compared with conventional extraction methods. In addition, the compound 7-hydroxymatairesinol, which has not previously been detected in cereals because of destructive extraction methods, was the dominant lignan in several cereals, including in barley. The main extraction conditions of ASE and the phenolic content obtained for barley samples found in the literature are reported in Table 6.

PFE has been widely applied for the extraction of phenolic compounds in recent years (Vichapong et al. 2010; Bonoli et al. 2004a,b; Milagros Delgado-Zamarreño et al. 2009). The applied high pressure, usually ranging from 4 to $20 \mathrm{MPa}$, ensures that the solvent is maintained in the liquid state at the applied temperature. This is the main reason for the use of pressure, although pressure has also been reported to help drive the solvent into the pores of the matrix, enhancing the analyte solubility (Joana Gil-Chávez et al. 2013; Mustafa and Turner 2011). This process needs less solvent, and the oxidative degradation of the phenolic compounds is lower, as the process is free of oxygen and light (Stalikas 2007; Vichapong et al. 2010; Wang and Weller 2006). PFE has been mainly used to optimize analytical extractions (Alonso-Salces et al. 2001), although few commercial applications exist in the
Fig. 2 Schematic diagram of a pressurized fluid extraction (PFE) system

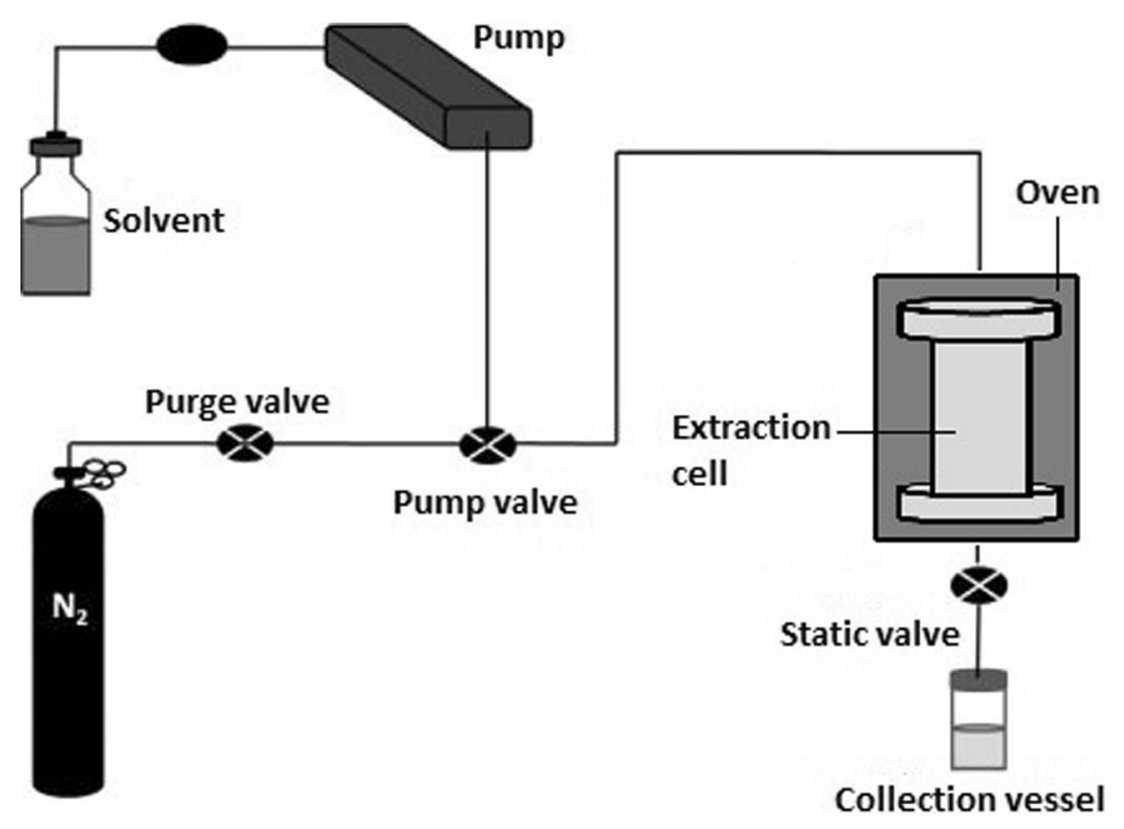


field of extraction of flavorings from natural products as an alternative to steam distillation. PFE generally requires less time and lower consumption of organic solvents than conventional techniques. This is the reason why PFE may have commercial interest as alternative extraction method to obtain bioactive compounds from by-products.

The extraction of phenolic compounds by PFE has been demonstrated in numerous studies which have presented several approaches to optimize the extraction conditions or evaluate their efficiency compared to other methods (Vichapong et al. 2010; Bonoli et al. 2004a,b; Milagros Delgado-Zamarreño et al. 2009). However, as already mentioned for other advanced techniques such as ASE, no reports were found concerning the extraction of polyphenols from BSG. Bonoli et al. (2004a,b) evaluated the recovery of phenolic compounds from barley by PFE. The extraction recovery of phenolics was compared to conventional SLE. PFE extracted less simple phenols and hydrolysable tannins compared to the conventional extraction method. Moreover, increasing the extraction temperature decreased the amount of phenolic compounds detected, probably due to their degradation at higher PFE temperatures. The highest amount of total phenolic compounds recovered was obtained when ethanol was used as extraction solvent ( $2.13 \pm 0.36 \mathrm{mg}$ phenols/g barley). Recently, Milagros Delgado-Zamarreño et al. (2009) applied a rapid and simple analytical method including PFE and liquid chromatography with electrochemical detection for the recovery of tocopherols $(\alpha-\mathrm{T}, \beta-\mathrm{T}, \gamma-\mathrm{T}$, and $\delta-\mathrm{T})$ and tocotrienols $(\alpha-\mathrm{T} 3, \beta-\mathrm{T} 3, \gamma-$ $\mathrm{T} 3$, and $\delta-\mathrm{T} 3$ ) from cereals, namely from wheat, rye, barley, maize, and oat. The optimized conditions were as follows: oven temperature, $50{ }^{\circ} \mathrm{C}$; pressure, $1600 \mathrm{psi}$; and one static cycle with a static time of $5 \mathrm{~min}$. At these conditions, only tocotrienols $(\beta+$ $\gamma)$-T3 and $\alpha$-T3 were detected in the case of barley, $4.5 \pm 0.9$ and $7.1 \pm 0.3 \mu \mathrm{g} / \mathrm{g}$, respectively. Another application of PFE was reported by Papagiannopoulos et al. (2002), which applied this extraction technique in the recovery of proanthocyanidins from malt samples. At the optimized conditions, temperature $60{ }^{\circ} \mathrm{C}$, pressure $100 \mathrm{MPa}, 10$-min static extraction time, and $14 \mathrm{~mL}$ solvent volume, the recovery of five main malt proanthocyanidins was $97 \%$, with a reproducibility of $5 \%$. The main applications of PFE technique for barley and malt samples are reported in Table 6.

\section{Ultrasound-Assisted Extraction}

Most extraction techniques consist of the manipulation of the solvent physical properties to reduce its superficial tension, to increase the solute solubility, and to improve the mass transfer rate; in some cases, these manipulations also induce changes in the solvent polarity (Azmir et al. 2013; Esclapez et al. 2011).

The development of ultrasound technology is not new; however, it is only recently that the main advances in the exploitation of power ultrasound have been achieved (Soria and Villamiel 2010). Ultrasound-assisted extraction (UAE) has been proposed as an alternative to conventional extraction techniques, providing higher recovery of targeted compounds with lower solvent consumption and/or faster analysis and bioactivity properties. The UAE technique consists in using mechanic vibrations caused by sound waves with frequencies higher than $20 \mathrm{kHz}$. Sound waves are intrinsically different from electromagnetic waves, because the latter can propagate through the vacuum, while sound waves need a physical medium to propagate. The mechanic vibrations cause expansion and compression cycles in the medium, creating cavities or microbubbles in the liquid. Eventually, the formed bubbles cannot absorb the energy any longer and will collapse: "Cavitation" takes place. This collapse causes a change in temperature and pressure within the bubble, and hence, energy for chemical reactions is generated. Extremely high temperatures of $5000{ }^{\circ} \mathrm{C}$ and pressures of 1000 bar have been measured (Soria and Villamiel 2010). Thus, the implosion of cavitation bubbles can hit the surface of the solid matrix, disintegrating the cells causing the release of the desired compounds (Joana Gil-Chávez et al. 2013).

Various studies have tested ultrasound and its effect on the extraction of polyphenols. Ultrasound has been shown to enhance the recovery of bioactive compounds, such as polyphenols, from different plant by-products (Vilkhu et al. 2008; Virot et al. 2010; Azmir et al. 2013). Some aspects related to the stability of the compounds extracted have not fully addressed; however, recent studies revealed that UAE of phenolic compounds were less degraded than others (Pingret et al. 2012). A study published by Tang et al. (2010) reported the application of UAE in BSG samples, although for the extraction of proteins. Optimum conditions for the extraction of protein were found to be the extraction time of $81.4 \mathrm{~min}$, ultrasonic power of $88.2 \mathrm{~W} / 100 \mathrm{~mL}$ of extractor, and solid-liquid ratio of $2.0 \mathrm{~g} / 100 \mathrm{~mL}$. The optimal protein yield obtained was $104.2 \mathrm{mg} / \mathrm{g}$ BSG. Recently, barley grain was also treated with UAE to extract polyphenols (Wang et al. 2013). Extraction temperature, ethanol concentration, solvent to material ratio, and extraction time were optimized using RSM. A temperature of $50{ }^{\circ} \mathrm{C}$, an ethanol concentration of $100 \%$, a solvent to material ratio of $60 \mathrm{mg} / \mathrm{L}$, and an extraction time of $18 \mathrm{~min}$ were determined as optimal conditions. These conditions resulted in an enhanced total polyphenol yield of $19.68 \mathrm{mg} \mathrm{GAE} / \mathrm{g}$ barley grain (Wang et al. 2013). Another interesting application of UAE has been developed for wheat bran, an important by-product of the cereal industry, which is rich in potentially health-promoting phenolic compounds (Wang et al. 2008). The optimum extraction conditions were as follows: ethanol concentration, $64 \%$; extraction temperature, $60{ }^{\circ} \mathrm{C}$; and extraction time, $25 \mathrm{~min}$. Under the abovementioned conditions, the TPC was $3.12 \mathrm{mg} \mathrm{GAE} / \mathrm{g}$ of wheat bran tested. 
The advantages of UAE include reduction in extraction time, energy, and use of solvent. Ultrasound energy for extraction also facilitates more effective mixing, faster energy transfer, reduced thermal gradients and extraction temperature, selective extraction, reduced equipment size, faster response to process extraction, and increased production (Joana GilChávez et al. 2013; Esclapez et al. 2011). Despite the wide utilization of UAE, the method encompasses two weaknesses, namely lack of uniformity in the distribution of ultrasound energy and decline of power with time (Wang and Weller 2006). Nevertheless, the UAE method can be used with the existing equipment, such as an ultrasonic bath with minimum alteration in its structure, and can be applied for aqueous extraction where organic solvents can be replaced with generally recognized as safe (GRAS) solvents, which, in turn, can reduce the solvent usage (Soria and Villamiel 2010).

The comparison of the reported extraction techniques currently used in the particular applications for BSG, barley, and malt samples is summarized in Table 6. In order to obtain the most effective and potential extract, it is necessary to take into account the characteristics of sample, the nature of solvents used for extraction, and the extraction procedure employed. Very often, the high yield of extraction will not ensure a high yield of bioactive components in the extract. For example, some bioactive components are very sensitive to oxygen and heat. In this case, more care should be taken to prevent the oxidation and thermal degradation of those components. Therefore, the yield and quality of bioactive components should also be considered when an extraction method is selected. Furthermore, and above all, conventional technologies have also well-known technological and scaleup boundaries that restrict the efficacy of the proposed methodologies and ultimately their commercial implementation (Galanakis 2013).

\section{Conclusions}

BSG as a residual waste would appear to have great potential if efficient extraction techniques are able to be achieved, given its volume, acquisition price, and supply chain benefits of availability from large centrally located breweries. Therefore, investigations focused on the recovery of high added value from this surplus have been intensified in the last decade. There are numerous reviews reporting the techniques to extract bioactive compounds from plant materials, food wastes, and other sources. However, references to the BSG in these reviews are scarce, specially taking into account its relevance as worldwide industrial waste. This is the first review focused on the phenolic compounds from BSG, barley, and malt, fundamental matrices for the brewing industry.

As reviewed herein, phenolic compounds can be recovered from BSG by several extraction methods, with the conventional SLE techniques, such as extraction with organic solvents and enzymatic and alkaline reactions, being the most used. Among these methods, SLE using 60\% $(v / v)$ acetone as solvent for $30 \mathrm{~min}$ at $60^{\circ} \mathrm{C}$ proved to be highly efficient to extract antioxidant phenolic compounds from BSG $(9.90 \mathrm{mg}$ GAE/g dry BSG). However, the use of emerging extraction techniques is increasing, and investigations are progressively focusing on the recovery of natural antioxidants by environmentally friendly techniques. Traditional SLE methods require a large quantity of solvent and are time consuming. Furthermore, the large amount of solvent used not only increases operating costs but also causes additional environmental problems.

Several novel extraction techniques have been developed as an alternative to conventional extraction methods, offering advantages with respect to extraction time, solvent consumption, extraction yields, and reproducibility. Recently, an efficient MAE process was applied for the extraction of polyphenols, and particularly of FA, from BSG with enhanced yield. The results showed that at the optimal conditions (15-min extraction time, $100^{\circ} \mathrm{C}$ extraction temperature, $20 \mathrm{~mL}$ of solvent, and maximum stirring speed), the yield of FA was $1.31 \pm 0.04 \%(w / w)$, which was fivefold higher than that obtained with conventional SLE techniques. Moreover, the developed extraction method considerably reduces extraction time, energy, and solvent consumption, while generating fewer wastes. As shown in this review, the use of further modern extraction techniques for the recovery of phenolic compounds from BSG, such as PFE, SFE, and UAE is clearly under exploited. The applications of these technologies to similar matrices, such as barley, malt, and cereal-based products, could be a starting point for an exploitation of these techniques. More research is required to improve the understanding of extraction mechanism, remove technical barriers, improve the design, and scale up of the novel extraction systems for their industrial applications.

Acknowledgements This work received financial support from the European Union (FEDER funds through COMPETE) and National Funds (Fundação para a Ciência e a Tecnologia (FCT) through project Pest-C/EQB/LA0006/2013. The work also received financial support from the European Union (FEDER funds) under the framework of QREN through project NORTE-07-0124-FEDER-000069. MMM wishes to acknowledge FCT for her postdoctoral grant (SFRH/BPD/ 97049/2013).

\section{References}

Abdel-Aal, E.-S. M., Akhtar, H., Rabalski, I., \& Bryan, M. (2014). Accelerated, microwave-assisted, and conventional solvent extraction methods affect anthocyanin composition from colored grains. Journal of Food Science, 79(2), C138-C146. doi:10.1111/17503841.12346. 
Aliyu, S., \& Bala, M. (2011). Brewer's spent grain: a review of its potentials and applications. African Journal of Biotechnology, 10(3), 324-331.

Alonso-Salces, R. M., Korta, E., Barranco, A., Berrueta, L. A., Gallo, B., \& Vicente, F. (2001). Pressurized liquid extraction for the determination of polyphenols in apple. Journal of Chromatography A, 933(1-2), 37-43. doi:10.1016/s0021-9673(01)01212-2.

Athanasios, M., Georgios, L., \& Michael, K. (2007). A rapid microwaveassisted derivatization process for the determination of phenolic acids in brewer's spent grains. Food Chemistry, 102(3), 606-611. doi:10.1016/j.foodchem.2006.05.040.

Awolu, O. O., \& Ibileke, I. O. (2011). Bioethanol production from brewer's spent grain, bread wastes and corn fiber. African Journal of Food Science, 5(3), 148-155.

Azmir, J., Zaidul, I. S. M., Rahman, M. M., Sharif, K. M., Mohamed, A., Sahena, F., et al. (2013). Techniques for extraction of bioactive compounds from plant materials: a review. Journal of Food Engineering, 117(4), 426-436. doi:10.1016/j.jfoodeng.2013.01.014.

Barbosa-Pereira, L., Pocheville, A., Angulo, I., Paseiro-Losada, P., \& Cruz, J. M. (2013). Fractionation and purification of bioactive compounds obtained from a brewery waste stream. BioMed Research International, 2013, 1-11. doi:10.1155/2013/408491.

Barros, F., Dykes, L., Awika, J. M., \& Rooney, L. W. (2013). Accelerated solvent extraction of phenolic compounds from sorghum brans. Journal of Cereal Science, 58(2), 305-312. doi:10.1016/j.jcs.2013. 05.011

Bartolomé, B., Faulds, C. B., \& Williamson, G. (1997). Enzymic release of ferulic acid from barley spent grain. Journal of Cereal Science, 25(3), 285-288. doi:10.1006/jers.1996.0091.

Bartolomé, B., \& Gómez-Cordovés, C. (1999). Barley spent grain: release of hydroxycinnamic acids (ferulic and p-coumaric acids) by commercial enzyme preparations. Journal of the Science of Food and Agriculture, 79(3), 435-439. doi:10.1002/(sici)10970010(19990301)79:3<435::aid-jsfa272>3.0.co;2-s.

Bartolomé, B., Gómez-Cordovés, C., Sancho, A. I., Díez, N., Ferreira, P., Soliveri, J., et al. (2003). Growth and release of hydroxycinnamic acids from brewer's spent grain by Streptomyces avermitilis CECT 3339. Enzyme and Microbial Technology, 32(1), 140-144. doi:10. 1016/S0141-0229(02)00277-6.

Bartolomé, B., Santos, M., Jiménez, J. J., del Nozal, M. J., \& GómezCordovés, C. (2002). Pentoses and hydroxycinnamic acids in brewer's spent grain. Journal of Cereal Science, 36(1), 51-58. doi: 10.1006/jcrs.2002.0442.

Belibasakis, N. G., \& Tsirgogianni, D. (1996). Effects of wet brewers grains on milk yield, milk composition and blood components of dairy cows in hot weather. Animal Feed Science and Technology, 57(3), 175-181. doi:10.1016/0377-8401(95)00860-8.

Bohnsack, C., Ternes, W., Büsing, A., \& Drotleff, A. (2011). Tocotrienol levels in sieving fraction extracts of brewer's spent grain. European Food Research and Technology, 232(4), 563-573. doi:10.1007/ s00217-010-1419-z.

Bonoli, M., Marconi, E., \& Caboni, M. F. (2004a). Free and bound phenolic compounds in barley (Hordeum vulgare L.) flours: evaluation of the extraction capability of different solvent mixtures and pressurized liquid methods by micellar electrokinetic chromatography and spectrophotometry. Journal of Chromatography A, 1057(1-2), 1-12. doi:10.1016/j.chroma.2004.09.024.

Bonoli, M., Verardo, V., Marconi, E., \& Caboni, M. F. (2004b). Antioxidant phenols in barley (Hordeum vulgare L.) flour: comparative spectrophotometric study among extraction methods of free and bound phenolic compounds. Journal of Agricultural and Food Chemistry, 52(16), 5195-5200. doi:10.1021/jf040075c.

Brányik, T., Vicente, A. A., Machado Cruz, J. M., \& Teixeira, J. A. (2001). Spent grains - a new support for brewing yeast immobilisation. Biotechnology Letters, 23(13), 1073-1078. doi:10.1023/a: 1010558407475 .
Carvalheiro, F., Duarte, L. C., Lopes, S., Parajó, J. C., Pereira, H., \& Gírio, F. M. (2005). Evaluation of the detoxification of brewery's spent grain hydrolysate for xylitol production by Debaryomyces hansenii CCMI 941. Process Biochemistry, 40(3-4), 1215-1223. doi:10.1016/j.procbio.2004.04.015.

Carvalheiro, F., Esteves, M. P., Parajó, J. C., Pereira, H., \& Gírio, F. M. (2004). Production of oligosaccharides by autohydrolysis of brewery's spent grain. Bioresource Technology, 91(1), 93-100. doi:10.1016/s0960-8524(03)00148-2.

Coelho, E., Rocha, M. A. M., Saraiva, J. A., \& Coimbra, M. A. (2014). Microwave superheated water and dilute alkali extraction of brewers' spent grain arabinoxylans and arabinoxylo-oligosaccharides. Carbohydrate Polymers, 99, 415-422.

Colombo, M. L., Corsini, A., Mossa, A., Sala, L., \& Stanca, M. (1998). Supercritical carbon dioxide extraction, fluorimetric and electrochemical high performance liquid chromatrographic detection of vitamin E from Hordeum vulgare L. Phytochemical Analysis, 9(4), 192-195. doi:10.1002/(SICI)1099-1565(199807/08)9:4<192::AIDPCA405>3.0.CO;2-D.

Conde, E., Moure, A., Domínguez, H., \& Parajó, J. C. (2008). Fractionation of antioxidants from Autohydrolysis of barley husks. Journal of Agricultural and Food Chemistry, 56(22), 10651-10659. doi:10.1021/jf801710a.

Dai, J., \& Mumper, R. J. (2010). Plant phenolics: extraction, analysis and their antioxidant and anticancer properties. Molecules, 15(10), 7313-7352.

Dar, B. N., \& Sharma, S. (2011). Total phenolic content of cereal brans using conventional and microwave assisted extraction. American Journal of Food Technology, 6(12), 1045-1053.

de Melo, M. M. R., Silvestre, A. J. D., \& Silva, C. M. (2014). Supercritical fluid extraction of vegetable matrices: applications, trends and future perspectives of a convincing green technology. The Journal of Supercritical Fluids, 92, 115-176. doi:10.1016/j. supflu.2014.04.007.

Dhiman, T. R., Bingham, H. R., \& Radloff, H. D. (2003). Production response of lactating cows fed dried versus wet brewers' grain in diets with similar dry matter Content1,2. Journal of Dairy Science, 86(9), 2914-2921.

Díaz-Reinoso, B., Moure, A., Domínguez, H., \& Parajó, J. C. (2006). Supercritical $\mathrm{CO}_{2}$ extraction and purification of compounds with antioxidant activity. Journal of Agricultural and Food Chemistry, 54(7), 2441-2469. doi:10.1021/jf052858j.

Duarte, L., Carvalheiro, F., Lopes, S., Marques, S., Parajo, J., \& Gírio, F. (2004). Comparison of two posthydrolysis processes of brewery's spent grain autohydrolysis liquor to produce a pentose-containing culture medium. Applied Biochemistry and Biotechnology, 115(13), 1041-1058. doi:10.1385/ABAB:115:1-3:1041.

Dudjak, J., Lachman, J., Miholová, D., Kolihová, D., \& Pivec, V. (2004). Effect of cadmium on polyphenol content in young barley plants (Hordeum vulgare L.) Plant Soil and Environment, 50, 471-477.

Dvořáková, M., Guido, L. F., Dostálek, P., Skulilová, Z., Moreira, M. M., \& Barros, A. A. (2008a). Antioxidant properties of free, soluble ester and insoluble-bound phenolic compounds in different barley varieties and corresponding malts. Journal of the Institute of Brewing, 114(1), 27-33. doi:10.1002/j.2050-0416.2008.tb00302.x.

Dvořáková, M., Moreira, M. M., Dostálek, P., Skulilová, Z., Guido, L. F., \& Barros, A. A. (2008b). Characterization of monomeric and oligomeric flavan-3-ols from barley and malt by liquid chromatography-ultraviolet detection-electrospray ionization mass spectrometry. Journal of Chromatography A, 1189(1-2), 398-405. doi:10. 1016/j.chroma.2007.10.080

Esclapez, M. D., García-Pérez, J. V., Mulet, A., \& Cárcel, J. A. (2011). Ultrasound-assisted extraction of natural products. Food Engineering Reviews, 3(2), 108-120.

Faulds, C., Sancho, A., \& Bartolomé, B. (2002). Mono- and dimeric ferulic acid release from brewer's spent grain by fungal feruloyl 
esterases. Applied Microbiology and Biotechnology, 60(4), 489494. doi:10.1007/s00253-002-1140-3.

Faulds, C. B., Mandalari, G., Lo Curto, R. B., Bisignano, G., \& Waldron, K. W. (2006). Influence of the arabinoxylan composition on the susceptibility of mono- and dimeric ferulic acid release by Humicola insolens feruloyl esterases. Journal of the Science of Food and Agriculture, 86(11), 1623-1630. doi:10.1002/jsfa.2480.

Faulds, C. B., Mandalari, G., LoCurto, R., Bisignano, G., \& Waldron, K. W. (2004). Arabinoxylan and mono- and dimeric ferulic acid release from brewer's grain and wheat bran by feruloyl esterases and glycosyl hydrolases from Humicola insolens. Applied Microbiology and Biotechnology, 64(5), 644-650. doi:10.1007/s00253-0031520-3.

Fernandez, M. P., Rodriguez, J. F., Garcia, M. T., de Lucas, A., \& Gracia, I. (2008). Application of supercritical fluid extraction to brewer's spent grain management. Industrial \& Engineering Chemistry Research, 47(5), 1614-1619. doi:10.1021/ie0708529.

Ferraz, A. I., Amorim, C., Tavares, T., \& Teixeira, J. A. (2015). Chromium(III) biosorption onto spent grains residual from brewing industry: equilibrium, kinetics and column studies. International journal of Environmental Science and Technology, 12(5), 15911602. doi:10.1007/s13762-014-0539-6.

Fillaudeau, L., Blanpain-Avet, P., \& Daufin, G. (2006). Water, wastewater and waste management in brewing industries. Journal of Cleaner Production, 14(5), 463-471. doi:10.1016/j.jclepro.2005.01.002.

Forssell, P., Kontkanen, H., Schols, H. A., Hinz, S., Eijsink, V. G. H., Treimo, J., et al. (2008). Hydrolysis of brewers' spent grain by carbohydrate degrading enzymes. Journal of the Institute of Brewing, 114(4), 306-314. doi:10.1002/j.2050-0416.2008.tb00774.x.

Fratianni, A., Caboni, M., Irano, M., \& Panfili, G. (2002). A critical comparison between traditional methods and supercritical carbon dioxide extraction for the determination of tocochromanols in cereals. European Food Research and Technology, 215(4), 353-358. doi:10.1007/s00217-002-0566-2.

Galanakis, C. M. (2013). Emerging technologies for the production of nutraceuticals from agricultural by-products: a viewpoint of opportunities and challenges. Food and Bioproducts Processing, 91(C4), 575-579. doi:10.1016/j.fbp.2013.01.004.

Gupta, M., Abu-Ghannam, N., \& Gallaghar, E. (2010). Barley for brewing: characteristic changes during malting, brewing and applications of its by-products. Comprehensive Reviews in Food Science and Food Safety, 9(3), 318-328.

Hernanz, D., Nuñez, V., Sancho, A. I., Faulds, C. B., Williamson, G., Bartolomé, B., et al. (2001). Hydroxycinnamic acids and ferulic acid dehydrodimers in barley and processed barley. Journal of Agricultural and Food Chemistry, 49(10), 4884-4888. doi:10. 1021/jf010530u.

Herrero, M., Castro-Puyana, M., Mendiola, J. A., \& Ibañez, E. (2013). Compressed fluids for the extraction of bioactive compounds. TrAC Trends in Analytical Chemistry, 43, 67-83. doi:10.1016/j.trac.2012. 12.008 .

Herrero, M., Mendiola, J. A., Cifuentes, A., \& Ibáñez, E. (2010). Supercritical fluid extraction: recent advances and applications. Journal of Chromatography A, 1217(16), 2495-2511. doi:10. 1016/j.chroma.2009.12.019.

Holtekjølen, A. K., Kinitz, C., \& Knutsen, S. H. (2006). Flavanol and bound phenolic acid contents in different barley varieties. Journal of Agricultural and Food Chemistry, 54(6), 2253-2260. doi:10.1021/ jf052394p.

Huige, N. (2006). Brewery by-products and effluents. In Handbook of Brewing, Second Edition (pp. 655-713, Food Science and Technology). CRC Press.

Inglett, G. E., Rose, D. J., Stevenson, D. C., Chen, D., \& Biswas, A. (2009). Total phenolics and antioxidant activity of water and ethanolic extracts from distillers dried grains with solubles with or without microwave irradiation. Cereal Chemistry, 86(6), 661-664.
Irakli, M. N., Samanidou, V. F., Biliaderis, C. G., \& Papadoyannis, I. N. (2012). Development and validation of an HPLC-method for determination of free and bound phenolic acids in cereals after solidphase extraction. Food Chemistry, 134(3), 1624-1632. doi:10. 1016/j.foodchem.2012.03.046.

Jay, A. J., Parker, M. L., Faulks, R., Husband, F., Wilde, P., Smith, A. C., et al. (2008). A systematic micro-dissection of brewers' spent grain. Journal of Cereal Science, 47(2), 357-364. doi:10.1016/j.jcs.2007. 05.006 .

Joana Gil-Chávez, G., Villa, J. A., Fernando Ayala-Zavala, J., Basilio Heredia, J., Sepulveda, D., Yahia, E. M., et al. (2013). Technologies for extraction and production of bioactive compounds to be used as nutraceuticals and food ingredients: an overview. Comprehensive Reviews in Food Science and Food Safety, 12(1), 5-23. doi:10.1111/1541-4337.12005.

Kasperovich, V. L., Grechushkin, A. I., Kupriyanov, A. V., \& Miroshnikov, S. A. (2009). Technology of utilizing brewery waste and use of the product obtained for feeding young bulls. Russian Agricultural Sciences, 35(4), 262-265. doi:10.3103/ S1068367409040144.

Klimek, P., Wimmer, R., Mishra, P. K., \& Kudela, J. (2017). Utilizing brewer's-spent-grain in wood-based particleboard manufacturing. Journal of Cleaner Production, 141, 812-817. doi:10.1016/j. jclepro.2016.09.152.

Ktenioudaki, A., Chaurin, V., Reis, S. F., \& Gallagher, E. (2012). Brewer's spent grain as a functional ingredient for breadsticks. International Journal of Food Science \& Technology, 47(8), 1765-1771. doi:10.1111/j.1365-2621.2012.03032.x.

Liazid, A., Palma, M., Brigui, J., \& Barroso, C. G. (2007). Investigation on phenolic compounds stability during microwave-assisted extraction. Journal of Chromatography A, 1140, 29-34.

Liguori, R., Soccol, C. R., Vandenberghe, L. P. D., Woiciechowski, A. L., $\&$ Faraco, V. (2015). Second generation ethanol production from brewers' spent grain. Energies, 8(4), 2575-2586.

Low, K. S., Lee, C. K., \& Liew, S. C. (2000). Sorption of cadmium and lead from aqueous solutions by spent grain. Process Biochemistry, 36(1-2), 59-64. doi:10.1016/S0032-9592(00)00177-1.

Luque de Castro, M. D., \& García-Ayuso, L. E. (1998). Soxhlet extraction of solid materials: an outdated technique with a promising innovative future. Analytica Chimica Acta, 369(1-2), 1-10. doi:10. 1016/S0003-2670(98)00233-5.

Mandalari, G., Faulds, C. B., Sancho, A. I., Saija, A., Bisignano, G., LoCurto, R., et al. (2005). Fractionation and characterisation of arabinoxylans from brewers' spent grain and wheat bran. Journal of Cereal Science, 42(2), 205-212. doi:10.1016/j.jcs.2005.03.001.

McCarthy, A. L., O'Callaghan, Y. C., Piggott, C. O., FitzGerald, R. J., \& O'Brien, N. M. (2013a). Brewers' spent grain; bioactivity of phenolic component, its role in animal nutrition and potential for incorporation in functional foods: a review. Proceedings of the Nutrition Society, 72(01), 117-125. doi:10.1017/S0029665112002820.

McCarthy, A. L., O'Callaghan, Y. C., Connolly, A., Piggott, C. O., FitzGerald, R. J., \& O'Brien, N. M. (2012). Phenolic extracts of brewers' spent grain (BSG) as functional ingredients - assessment of their DNA protective effect against oxidant-induced DNA single strand breaks in U937 cells. Food Chemistry, 134(2), 641-646. doi: 10.1016/j.foodchem.2012.02.133.

McCarthy, A. L., O'Callaghan, Y. C., Neugart, S., Piggott, C. O., Connolly, A., Jansen, M. A. K., et al. (2013b). The hydroxycinnamic acid content of barley and brewers' spent grain (BSG) and the potential to incorporate phenolic extracts of BSG as antioxidants into fruit beverages. Food Chemistry, 141(3), 2567-2574. doi:10.1016/j.foodchem.2013.05.048.

Mendiola, J. A., Herrero, M., Cifuentes, A., \& Ibanez, E. (2007). Use of compressed fluids for sample preparation: food applications. Journal of Chromatography A, 1152(1-2), 234-246. doi:10.1016/ j.chroma.2007.02.046. 
Meneses, N. G. T., Martins, S., Teixeira, J. A., \& Mussatto, S. I. (2013). Influence of extraction solvents on the recovery of antioxidant phenolic compounds from brewer's spent grains. Separation and Purification Technology, 108, 152-158. doi:10.1016/j.seppur.2013. 02.015 .

Milagros Delgado-Zamarreño, M., Bustamante-Rangel, M., SierraManzano, S., Verdugo-Jara, M., \& Carabias-Martínez, R. (2009). Simultaneous extraction of tocotrienols and tocopherols from cereals using pressurized liquid extraction prior to LC determination. Journal of Separation Science, 32(9), 1430-1436. doi:10.1002/jssc. 200800707.

Moreira, M. M., Morais, S., Barros, A. A., Delerue-Matos, C., \& Guido, L. F. (2012). A novel application of microwave-assisted extraction of polyphenols from brewer's spent grain with HPLC-DAD-MS analysis. Analytical and Bioanalytical Chemistry, 403(4), 10191029. doi:10.1007/s00216-011-5703-y.

Moreira, M. M., Morais, S., Carvalho, D. O., Barros, A. A., DelerueMatos, C., \& Guido, L. F. (2013). Brewer's spent grain from different types of malt: evaluation of the antioxidant activity and identification of the major phenolic compounds. Food Research International, 54(1), 382-388. doi:10.1016/j.foodres.2013.07.023.

Mussatto, S., Fernandes, M., Dragone, G., Mancilha, I., \& Roberto, I. (2007b). Brewer's spent grain as raw material for lactic acid production by Lactobacillus delbrueckii. Biotechnology Letters, 29(12), 1973-1976. doi:10.1007/s10529-007-9494-3.

Mussatto, S. I. (2009). Biotechnological potential of brewing industry byproducts. In P. Nigam \& A. Pandey (Eds.), Biotechnology for AgroIndustrial Residues Utilisation (pp. 313-326). Netherlands: Springer.

Mussatto, S. I. (2014). Brewer's spent grain: a valuable feedstock for industrial applications. Journal of the Science of Food and Agriculture, 94(7), 1264-1275.

Mussatto, S. I., Dragone, G., \& Roberto, I. C. (2006). Brewers' spent grain: generation, characteristics and potential applications. Journal of Cereal Science, 43(1), 1-14.

Mussatto, S. I., Dragone, G., \& Roberto, I. C. (2007a). Ferulic and pcoumaric acids extraction by alkaline hydrolysis of brewer's spent grain. Industrial Crops and Products, 25(2), 231-237. doi:10.1016/ j.indcrop.2006.11.001.

Mussatto, S. I., Fernandes, M., Mancilha, I. M., \& Roberto, I. C. (2008). Effects of medium supplementation and $\mathrm{pH}$ control on lactic acid production from brewer's spent grain. Biochemical Engineering Journal, 40(3), 437-444. doi:10.1016/j.bej.2008.01.013.

Mussatto, S. I., Moncada, J., Roberto, I. C., \& Cardona, C. A. (2013). Techno-economic analysis for brewer's spent grains use on a biorefinery concept: the Brazilian case. Bioresource Technology, 148, 302-310. doi:10.1016/j.biortech.2013.08.046.

Mussatto, S. I., \& Roberto, I. C. (2008). Establishment of the optimum initial xylose concentration and nutritional supplementation of brewer's spent grain hydrolysate for xylitol production by Candida guilliermondii. Process Biochemistry, 43(5), 540-546. doi:10.1016/j.procbio.2008.01.013.

Mustafa, A., \& Turner, C. (2011). Pressurized liquid extraction as a green approach in food and herbal plants extraction: a review. Analytica Chimica Acta, 703(1), 8-18. doi:10.1016/j.aca.2011.07.018.

Okamoto, H., Sato, K., Yagi, N., Inoue, M., Yamasaki, S., Ishida, S., et al. (2002). Development of production process of charcoal bricks from spent grain. Kagaku Kogaku Ronbunshu, 28(2), 137-142.

Omwamba, M., \& Hu, Q. (2010). Antioxidant activity in barley (Hordeum vulgareL.) grains roasted in a microwave oven under conditions optimized using response surface methodology. Journal of Food Science, 75(1), C66-C73. doi:10.1111/j.1750-3841.2009. 01426.x.

Oufnac, D. S., Xu, Z., Sun, T., Sabliov, C., Prinyawiwatkul, W., \& Godber, J. S. (2007). Extraction of antioxidants from wheat bran using conventional solvent and microwave-assisted methods. Cereal Chemistry, 84(2), 125-129.

Panagiotou, G., Granouillet, P., \& Olsson, L. (2006). Production and partial characterization of arabinoxylan-degrading enzymes by Penicillium brasilianum under solid-state fermentation. Applied Microbiology and Biotechnology, 72(6), 1117-1124. doi:10.1007/ s00253-006-0394-6.

Papagiannopoulos, M., Zimmermann, B., Mellenthin, A., Krappe, M., Maio, G., \& Galensa, R. (2002). Online coupling of pressurized liquid extraction, solid-phase extraction and high-performance liquid chromatography for automated analysis of proanthocyanidins in malt. Journal of Chromatography A, 958(1-2), 9-16. doi:10.1016/ S0021-9673(02)00364-3.

Pedro Silva, J., Sousa, S., Rodrigues, J., Antunes, H., Porter, J. J., Gonçalves, I., et al. (2004). Adsorption of acid orange 7 dye in aqueous solutions by spent brewery grains. Separation and Purification Technology, 40(3), 309-315. doi:10.1016/j.seppur. 2004.03.010.

Pereira, C., \& Meireles, M. A. (2010). Supercritical fluid extraction of bioactive compounds: fundamentals, applications and economic perspectives. Food and Bioprocess Technology, 3(3), 340-372. doi:10.1007/s11947-009-0263-2.

Pingret, D., Fabiano-Tixier, A. S., Bourvellec, C. L., Renard, C. M. G. C., \& Chemat, F. (2012). Lab and pilot-scale ultrasound-assisted water extraction of polyphenols from apple pomace. Journal of Food Engineering, 111(1), 73-81. doi:10.1016/j.jfoodeng.2012.01.026.

Pires, E. J., Ruiz, H. A., Teixeira, J. A., \& Vicente, A. A. (2012). A new approach on brewer's spent grains treatment and potential use as lignocellulosic yeast cells carriers. Journal of Agricultural and Food Chemistry, 60(23), 5994-5999. doi:10.1021/jf300299m.

Pourali, O., Asghari, F. S., \& Yoshida, H. (2010). Production of phenolic compounds from rice bran biomass under subcritical water conditions. Chemical Engineering Journal, 160(1), 259-266. doi:10. 1016/j.cej.2010.02.057.

Quinde-Axtell, Z., \& Baik, B. K. (2006). Phenolic compounds of barley grain and their implication in food product discoloration. Journal of Agricultural and Food Chemistry, 54(26), 9978-9984. doi:10.1021/ jf060974w.

Ramos, L., Kristenson, E. M., \& Brinkman, U. A. T. (2002). Current use of pressurised liquid extraction and subcritical water extraction in environmental analysis. Journal of Chromatography A, 975(1), 329. doi:10.1016/S0021-9673(02)01336-5.

Reis, S. F., \& Abu-Ghannam, N. (2014). Antioxidant capacity, arabinoxylans content and in vitro glycaemic index of cereal-based snacks incorporated with brewer's spent grain. LWT - Food Science and Technology, 55(1), 269-277. doi:10.1016/j.1wt.2013.09.004.

Robertson, J. A., I'Anson, K. J. A., Treimo, J., Faulds, C. B., Brocklehurst, T. F., Eijsink, V. G. H., et al. (2010). Profiling brewers' spent grain for composition and microbial ecology at the site of production. LWT - Food Science and Technology, 43(6), 890-896. doi:10.1016/j.lwt.2010.01.019.

Roos, A. A., Persson, T., Krawczyk, H., Zacchi, G., \& Stalbrand, H. (2009). Extraction of water-soluble hemicelluloses from barley husks. Bioresource Technology, 100(2), 763-769. doi:10.1016/j. biortech.2008.07.022.

Routray, W., \& Orsat, V. (2012). Microwave-assisted extraction of flavonoids: a review. Food and Bioprocess Technology, 5(2), 409-424. doi:10.1007/s11947-011-0573-z.

Russ, W., Mörtel, H., \& Meyer-Pittroff, R. (2005). Application of spent grains to increase porosity in bricks. Construction and Building Materials, 19(2), 117-126. doi:10.1016/j.conbuildmat.2004.05.014.

Santos, M., Jiménez, J. J., Bartolomé, B., Gómez-Cordovés, C., \& del Nozal, M. J. (2003). Variability of brewer's spent grain within a brewery. Food Chemistry, 80(1), 17-21. doi:10.1016/s03088146(02)00229-7. 
Shivashankar, S., Sumathi, M., Krishnakumar, N. K., \& Rao, V. K. (2015). Role of phenolic acids and enzymes of phenylpropanoid pathway in resistance of chayote fruit (Sechium edule) against infestation by melon fly, Bactrocera cucurbitae. Annals of Applied Biology, 166(3), 420-433. doi:10.1111/Aab.12194.

Smeds, A. I., Eklund, P. C., Sjöholm, R. E., Willför, S. M., Nishibe, S., Deyama, T., et al. (2007). Quantification of a broad spectrum of lignans in cereals, oilseeds, and nuts. Journal of Agricultural and Food Chemistry, 55(4), 1337-1346. doi:10.1021/jf0629134.

Soria, A. C., \& Villamiel, M. (2010). Effect of ultrasound on the technological properties and bioactivity of food: a review. Trends in Food Science and Technology, 21, 323-331.

Spinelli, S., Conte, A., \& Del Nobile, M. A. (2016a). Microencapsulation of extracted bioactive compounds from brewer's spent grain to enrich fish-burgers. Food and Bioproducts Processing, 100, 450-456.

Spinelli, S., Conte, A., Lecce, L., Padalino, L., \& Del Nobile, M. A. (2016b). Supercritical carbon dioxide extraction of brewer's spent grain. Journal of Supercritical Fluids, 107, 69-74. doi:10.1016/j. supflu.2015.08.017.

Stalikas, C. D. (2007). Extraction, separation, and detection methods for phenolic acids and flavonoids. Journal of Separation Science, 30(18), 3268-3295. doi:10.1002/jssc.200700261.

Stevenson, D. G., Inglett, G. E., Chen, D., Biswas, A., Eller, F. J., \& Evangelista, R. L. (2008). Phenolic content and antioxidant capacity of supercritical carbon dioxide-treated and air-classified oat bran concentrate microwave-irradiated in water or ethanol at varying temperatures. Food Chemistry, 108(1), 23-30. doi:10.1016/j.foodchem. 2007.08.060.

Sun, R., \& Sun, X.-F. (2001). Separation and characterization of lipophilic extracts from barley straw. Separation Science and Technology, 36(13), 3027-3048. doi:10.1081/SS-100107644.

Szwajgier, D., Waśko, A., Targoński, Z., Niedźwiadek, M., \& Bancarzewska, M. (2010). The use of a novel ferulic acid esterase from Lactobacillus acidophilus K1 for the release of phenolic acids from brewer's spent grain. Journal of the Institute of Brewing, 116(3), 293-303. doi:10.1002/j.2050-0416.2010.tb00434.x.

Tang, D.-S., Tian, Y.-J., He, Y.-Z., Li, L., Hu, S.-Q., \& Li, B. (2010). Optimisation of ultrasonic-assisted protein extraction from brewer's spent grain. Czech Journal Food Science, 28, 9-17.

Tang, Z., Cenkowski, S., \& Izydorczyk, M. (2005). Thin-layer drying of spent grains in superheated steam. Journal of Food Engineering, 67(4), 457-465. doi:10.1016/j.jfoodeng.2004.04.040.

Tang, Z., Cenkowski, S., \& Muir, W. E. (2004). Modelling the superheated-steam drying of a fixed bed of brewers' spent grain. Biosystems Engineering, 87(1), 67-77. doi:10.1016/j. biosystemseng.2003.09.008.

Terrasan, C. R. F., Temer, B., Duarte, M. C. T., \& Carmona, E. C. (2010). Production of xylanolytic enzymes by Penicillium janczewskii. Bioresource Technology, 101(11), 4139-4143. doi:10.1016/j. biortech.2010.01.011.

Tsubaki, S., Sakamoto, M., \& Azuma, J. I. (2010). Microwave-assisted extraction of phenolic compounds from tea residues under autohydrolytic conditions. Food Chemistry, 123(4), 1255-1258. doi:10.1016/j.foodchem.2010.05.088.
Valérie, C. (2000). Microwave-assisted solvent extraction of environmental samples. TrAC Trends in Analytical Chemistry, 19(4), 229-248. doi:10.1016/s0165-9936(99)00185-5.

Vellingiri, V., Amendola, D., \& Spigno, G. (2014). Screening of four different agro-food by-products for the recovery of antioxidants and cellulose. Chemical Engineering Transactions, 37, 757-762.

Vichapong, J., Sookserm, M., Srijesdaruk, V., Swatsitang, P., \& Srijaranai, S. (2010). High performance liquid chromatographic analysis of phenolic compounds and their antioxidant activities in rice varieties. LWT - Food Science and Technology, 43(9), 13251330. doi:10.1016/j.lwt.2010.05.007.

Vilkhu, K., Mawson, R., Simons, L., \& Bates, D. (2008). Applications and opportunities for ultrasound assisted extraction in the food industry-a review. Innovative Food Science \& Emerging Technologies, 9(2), 161-169. doi:10.1016/j.ifset.2007.04.014.

Virot, M., Tomao, V., Le Bourvellec, C., Renard, C. M. C. G., \& Chemat, F. (2010). Towards the industrial production of antioxidants from food processing by-products with ultrasound-assisted extraction. Ultrasonics Sonochemistry, 17(6), 1066-1074. doi:10.1016/j. ultsonch.2009.10.015.

Wang, D., Sakoda, A., \& Suzuki, M. (2001). Biological efficiency and nutritional value of Pleurotus ostreatus cultivated on spent beer grain. Bioresource Technology, 78(3), 293-300. doi:10.1016/ S0960-8524(01)00002-5.

Wang, J., Sun, B., Cao, Y., Tian, Y., \& Li, X. (2008). Optimisation of ultrasound-assisted extraction of phenolic compounds from wheat bran. Food Chemistry, 106(2), 804-810. doi:10.1016/j.foodchem. 2007.06.062.

Wang, L., \& Weller, C. L. (2006). Recent advances in extraction of nutraceuticals from plants. Trends in Food Science \& Technology, 17(6), 300-312. doi:10.1016/j.tifs.2005.12.004.

Wang, X. J., Qi, J. C., Wang, X., \& Cao, L. P. (2013). Extraction of polyphenols from barley (Hordeum vulgare L.) grain using ultrasound-assisted extraction technology. [Article]. Asian Journal of Chemistry, 25(3), 1324-1330.

Wijngaard, H., Hossain, M. B., Rai, D. K., \& Brunton, N. (2012). Techniques to extract bioactive compounds from food by-products of plant origin. Food Research International, 46(2), 505-513. doi: 10.1016/j.foodres.2011.09.027.

Xiros, C., \& Christakopoulos, P. (2009). Enhanced ethanol production from brewer's spent grain by a Fusarium oxysporum consolidated system. Biotechnology for Biofuels, 2(4), 1-12.

Xiros, C., Moukouli, M., Topakas, E., \& Christakopoulos, P. (2009). Factors affecting ferulic acid release from brewer's spent grain by Fusarium oxysporum enzymatic system. Bioresource Technology, 100(23), 5917-5921. doi:10.1016/j.biortech.2009.06.018.

Xiros, C., Topakas, E., Katapodis, P., \& Christakopoulos, P. (2008). Hydrolysis and fermentation of brewer's spent grain by Neurospora crassa. Bioresource Technology, 99(13), 5427-5435. doi:10.1016/j.biortech.2007.11.010.

Zigoneanu, I. G., Williams, L., Xu, Z., \& Sabliov, C. M. (2008). Determination of antioxidant components in rice bran oil extracted by microwave-assisted method. Bioresource Technology, 99(11), 4910-4918. doi:10.1016/j.biortech.2007.09.067. 